\title{
WHY ARE COMPANIES FREEZING THEIR PENSIONS?
}

\author{
Alicia H. Munnell and Mauricio Soto* \\ With the assistance of \\ J.P. Aubry and Christopher J. Baum \\ CRR WP 2007-22 \\ Released: December 2007 \\ Draft Submitted: October 2007 \\ Center for Retirement Research at Boston College \\ Hovey House \\ 140 Commonwealth Avenue \\ Chestnut Hill, MA 02467 \\ Tel: 617-552-1762 Fax: 617-552-0191 \\ http://www.bc.edu/crr
}

\begin{abstract}
* Alicia H. Munnell is the Director of the Center for Retirement Research at Boston College (CRR) and the Peter F. Drucker Professor of Management Sciences at Boston College Carroll School of Management. Mauricio Soto is a senior research associate at the CRR. J.P Aubry is a research associate and Christopher J. Baum is an undergraduate research assistant at the CRR. The research reported herein was performed pursuant to a grant from the U.S. Social Security Administration (SSA) funded as part of the Retirement Research Consortium. The opinions and conclusions expressed are solely those of the authors and should not be construed as representing the opinions or policy of SSA, any agency of the Federal Government, or Boston College.

(C) 2007, by Alicia H. Munnell and Mauricio Soto. All rights reserved. Short sections of text, not to exceed two paragraphs, may be quoted without explicit permission provided that full credit, including (C) notice, is given to the source.
\end{abstract}




\title{
About the Center for Retirement Research
}

The Center for Retirement Research at Boston College, part of a consortium that includes parallel centers at the University of Michigan and the National Bureau of Economic Research, was established in 1998 through a grant from the Social Security Administration. The Center's mission is to produce first-class research and forge a strong link between the academic community and decision makers in the public and private sectors around an issue of critical importance to the nation's future. To achieve this mission, the Center sponsors a wide variety of research projects, transmits new findings to a broad audience, trains new scholars, and broadens access to valuable data sources.

\author{
Center for Retirement Research at Boston College \\ Hovey House \\ 140 Commonwealth Avenue \\ Chestnut Hill, MA 02467 \\ phone: 617-552-1762 fax: 617-552-0191 \\ e-mail: crr@bc.edu \\ www.bc.edu/crr
}

\author{
Affiliated Institutions: \\ American Enterprise Institute \\ The Brookings Institution \\ Center for Strategic and International Studies \\ Massachusetts Institute of Technology \\ Syracuse University \\ Urban Institute
}




\begin{abstract}
Defined benefit plans in the private sector are on the decline. And the early $21^{\text {st }}$ century produced an uptick in the pace of decline driven by the financially devastating impact of the 'perfect storm' of plummeting stock prices and low interest rates, legislation that will require underfunded plans to increase their contributions, and accounting changes that will force fluctuations in pension finance onto the earnings statement and will likely eliminate the smoothing available under current rules. Increased volatility is not acceptable to corporate managers and may, in large part, explain why large healthy companies have taken steps to end their defined benefit plans.

In an attempt to identify factors that led specific companies to freeze their plans, this paper explores the relationship between the probability that a plan was frozen and characteristics of the plan, the firm, and the industry. The results imply that plans where credit balances are high relative to income, legacy costs are substantial and funding ratios are low have a higher probability of being frozen. That makes sense in that plans with these characteristics are likely to have the most impact on future earnings under the Financial Accounting Standards Board's expected reporting requirements. It is reasonable to expect more plans with these characteristics to freeze in the future.
\end{abstract}


The shift in pension coverage from defined benefit plans to 401(k)s has been underway since 1981. This shift was the result of three developments; 1) the addition of 401(k) provisions to existing thrift and profit sharing plans; 2) a surge of new 401(k) plan formation in the 1980s; and 3) the virtual halt in the formation of new defined benefit plans. Shutting down a defined benefit plan and replacing it with a 401(k) plan was an extremely rare event, particularly among large sponsors. Historically, the only large companies closing their defined benefit pension plans were facing bankruptcy or struggling to stay alive. Now the pension landscape has changed. Today, large healthy companies are closing their defined benefit plans, and the pathway to that closure is a 'freeze.' This paper examines why companies are freezing their plans, what factors affect the decision to freeze a plan, and what the results mean for the future of defined benefit plans.

The paper is structured as follows. Section I describes the long-term forces behind the shift from defined benefit plans to defined contribution plans, as well as recent developments such as the 'perfect storm' and regulatory and accounting changes. Section II explains why the early $21^{\text {st }}$ century was always going to be a particularly challenging period for defined benefit plans. Section III discusses why companies have resorted to freezing their plans and describes alternative types of freezes. Section IV uses the Labor Department's Form 5500s, Compustat, and data from press releases and SEC filings to identify the factors that led to plan freezes during the last four years. Section V concludes.

\section{Economic Factors Undermine Desirability of Defined Benefit Plans}

The nature of employer-sponsored plans has changed dramatically in the last 25 years. In the early 1980s, most workers with pensions were covered by a defined benefit plan, either exclusively or in combination with a supplementary defined contribution plan. Today, most workers with pensions rely solely on a defined contribution plan usually a 401(k) (see Figure 1). The question is how pension coverage moved from there to here. The question can be answered on two levels - the mechanics and the underlying forces - both are relevant to the topic of pension freezes. 
The Mechanics of the Shift from Defined Benefit Plans

In terms of the mechanics, the first point worth emphasizing is that - until the recent round of 'pension freezes' - actually shutting down a large defined benefit plan and shifting coverage to a 401(k) plan was an extremely rare event, particularly among large plans. ${ }^{1}$ Instead of conversions from defined benefit plans, the spread of coverage under 401(k) plans proceeded in three steps.

Initial coverage under 401(k)s resulted from the addition of 401(k) provisions to traditional thrift and profit-sharing plans in the early 1980s. This was an obvious move because thrift plans, which generally served as supplements to defined benefit plans, required employees to make after-tax contributions. Since 401(k) plans allowed pre-tax contributions, introducing a 401(k) provision meant employees could maintain their contribution level and see an increase in take-home pay. In the case of profit sharing plans, the shift to 401(k)s and voluntary participation allowed employers to reduce the profits distributed to employees.

The second step in the growth of 401(k) coverage was a surge in new plan formation in the 1980s. Initial applications to the Internal Revenue Service (IRS) for determination letters, which is an imperfect but useful measure of plan formation, show that during the 1960s and into the 1970s defined benefit and defined contribution plan formations grew in lock step. ${ }^{2}$ After 1975, the picture changed dramatically, and the formation of defined contribution plans took off. This surge continued through the

\footnotetext{
${ }^{1}$ Ippolito (1999) followed a sample of 249 defined benefit plans with at least 500 participants over the period 1987 through 1995; of the 249 original plans, 214 remained in 1995. Of the 35 that sponsors terminated, 3 were replaced by a new defined benefit plan; 14 by no new plan; and only 18 by a defined contribution plan. In other words, most participants in the original sample were still in a defined benefit plan at the end of the study. These results are consistent with those of two other studies, Kruse (1995) and Papke et al. (1996), even though the various studies adopted different methodologies. The first tracked all pension plans from 1980 to 1986 using data from the Form 5500 and the second surveyed a sample of 401(k) plans in 1987 to see if they had replaced a defined benefit plan. In each case, the researchers found that most new 401(k) plans had not replaced a preexisting defined benefit plan.

${ }^{2}$ Employers are not required to obtain an IRS determination letter to verify the qualified status of a newly initiated plan or prior to terminating a current plan. However, many do in order to provide assurance that the plan is qualified under IRC section 401(a) and the trust is exempt under section 501(a) (in the event of a new plan), and to reduce the risk of an IRS audit (in the event of plan termination). Although the issuance of determination letters is not an exact measure of new plan formation or termination, it provides useful insight into current plan and participant trends (see U.S. Department of the Treasury, 2007).
} 
1980s, after the emergence of 401(k) plans. A second surge in 401(k) plans occurred during the heyday of the 1990s (see Figure 2).

The third factor in the shift to 401(k) coverage was a spike in defined benefit terminations during the late 1980s and early 1990s. The largest and most dramatic terminations were due to sponsor bankruptcy, most visibly in the steel and airline industries. Terminations also increased sharply after the Tax Reform Act of 1986 placed restrictions on very small defined benefit plans that benefited only highly paid individuals. Applications dropped after 1990 when the government placed an excise tax on the reversion of money from overfunded plans. These developments cut the number of defined benefit plans by more than 25 percent. ${ }^{3}$

In short, the shift in pension coverage started with the addition of a 401(k) feature to existing supplementary defined contribution plans, spread through the establishment of 401(k) plans at new companies in the late 1980s and again in the mid-1990s, and then gained prominence as many defined benefit plans terminated.

\section{Reasons for the Shift}

Why did 401(k) coverage spread so rapidly? The short answer is that $401(\mathrm{k})$ plans had enormous appeal to both employees and employers. A slightly longer explanation is that, on the demand side, the tastes of youth became more important in the labor market and a booming stock market made investing look easy. On the supply side, the structure of industry changed and defined benefit plans became increasingly expensive.

The employees' perspective. In the 1970s and 1980s, the baby boom generation and married women flooded into the labor market. ${ }^{4}$ For both these groups, the immediate reward of an account which they could control and take with them as they moved from job to job had much greater appeal than the delayed gratification of a defined benefit pension, which would provide meaningful benefits only if they spent most of their career with the same employer. In the case of married women, this preference was quite

\footnotetext{
3 The number of single employer plans insured by the PBGC went from 112,208 in 1985 to 82,717 by the end of 1991. See Pension Benefit Guaranty Corporation (2006).

${ }^{4}$ The labor force participation rate for married women rose from 40.5 percent in 1970 to 49.8 percent in 1980 and 58.4 percent in 1990 (U.S. Bureau of the Census, 2005, Table 585).
} 
rational given that they were likely to be in and out of the labor force as they attempted to combine career and family. The choice may or may not have been smart for young males. But the decline in labor unions weakened the voice of older workers and perhaps the support for a longer view towards work and retirement. ${ }^{5}$

If the stock market had faltered during the early years, young workers might have thought twice about the wisdom of managing their own retirement assets, but the debut of 401(k) plans coincided with the longest bull market in the country's history. Between 1982 and 2000, stock prices rose at annual rate of 16.9 percent compared to 8.7 percent between 1955 and 1981. With approximately half of 401(k) assets invested in equities, employees saw their accounts grow rapidly. Most people became convinced that investing was easy and that they could do much better at managing their own money than stodgy sponsors of defined benefit plans. Thus, 401(k) plans were embraced by employees.

The employers' perspective. From the employers' perspective, 401(k) plans offered a form of pension that their workers appreciated. Moreover, for the employer these plans eliminated the significant demographic risks involved in funding future retirement annuities. And the cost of a 401(k) plan was highly predictable, which became increasingly important during the 1980s as the economic environment became more competitive. These advantages of 401(k) plans would not have carried the day, however, if the need to encourage long service - a key factor in the design of traditional defined benefit plans - remained important.

But the nature of industry was changing dramatically. Employment was declining in large, unionized, manufacturing firms, which typically offered defined benefit plans, and was growing in "high-tech" firms and small, non-unionized companies in the services and trade sectors, which typically did not. Defined benefit plans are a sensible arrangement for large well-established firms; they are ill suited to many of the firms in the service industry, where companies come and go. Several studies find that changes in

\footnotetext{
${ }^{5}$ By 1983, only 16.5 percent of private sector wage and salary workers were union members. That number has since declined to 7.8 percent in 2005 (U.S. Bureau of the Census, 2005, Table 647).
} 
industry composition, unionization, and firm size account for about half the decline in defined benefit coverage. ${ }^{6}$

Even large organizations were reorganized in ways that reduced the value of longterm relationships between employer and employee. ${ }^{7}$ The new technologies arising in the area of information processing made the pyramid structure that had evolved for the mass production of standardized goods and services less useful. ${ }^{8}$ New organizational arrangements were required to efficiently tap a more highly educated workforce. The response was to flatten the organization and break it into smaller units and teams that were responsible for particular projects or products. Moreover, the nature of the work required more in the way of generic human capital as opposed to firm-specific skills. To compensate outstanding employees, rewards needed to be based on performance rather than on long service. In such organizations, defined benefit plans were not just unnecessary, they were an actual hindrance. They forced management to spend money on adequate but unexceptional employees, since defined benefit plans rewarded older workers with firm-specific skills. They also made it expensive for managers to hire and difficult for managers to fire mid-career employees.

Just as employers had increasingly little to gain by offering pensions, the costs of such benefits also began to rise. Workers were living longer, making life-time annuities increasingly expensive. The reduction in inflation in the 1980s and 1990s raised the real cost of un-indexed lifetime payments. In less-than-fully-funded plans, a dramatic increase in the number of retirees required large contributions relative to the size of the company. Finally, because employer plans held a significant portion of their assets in equities, large maturing plans produced significant volatility in company earnings and cash flow.

The regulatory environment also caused existing small firms and new companies established in the 1980s and 1990s to opt for a 401(k). The Employee Retirement Income Security Act of 1974 (ERISA) imposed minimum standards for participation,

\footnotetext{
${ }^{6}$ See, for example, Andrews (1992), Gustman and Steinmeier (1992), and Ippolito (1995).

7 Interestingly, the percent of the workforce employed by large organizations did not decline by as much as commonly thought. In 1972, 27.9 percent of the labor force worked for a firm with more than 10,000 employees. This percentage dropped to 24.2 percent in 1982 and was 24.4 percent in 1992 (U.S. Bureau of the Census, 1994).

${ }^{8}$ The following argument was developed by Sass (1997).
} 
vesting, and funding and required firms to insure pension benefits by paying premiums to the Pension Benefit Guaranty Corporation (PBGC). In addition to ERISA, during the 1980s Congress passed significant pension legislation every few years. ${ }^{9}$ Congress also repeatedly raised PBGC premiums and imposed an excise tax on employers who claim the excess assets of terminated defined benefit plans. The cumulative impact of the legislative changes increased the relative costs of defined benefit plans, particularly for small plans. ${ }^{10}$

In summary, the appeal of visible account balances and the sense of control provided by 401(k) plans, the response of the workplace to technological advances, the increased labor force participation of married women, the increased educational attainment of young workers, and regulatory costs all contributed to the dramatic shift in pension coverage from defined benefit to 401(k) plans.

\section{The $21^{\text {st }}$ Century Brings More Trouble}

Sponsors of defined benefit plans began the $21^{\text {st }}$ century by facing the 'perfect storm' of a declining stock market and very low interest rates. As assets in the pension funds plummeted and projected liabilities increased, funding rules required many plan sponsors to inject a significant amount of cash into their pension funds. Figure 3 shows the sudden increase in contributions after 2000, from an average annual amount of about $\$ 30$ billion per year between 1980 and 2000 to $\$ 45$ billion in 2001 and about $\$ 100$ billion in 2002 and 2003. Thus, market volatility suddenly made defined benefit plans considerably more expensive, with major implications for the sponsors' cash flow and financial condition.

In addition to the 'perfect storm,' sponsors of defined benefit plans faced the likelihood that the rules governing these plans would change in a way that would make

\footnotetext{
${ }^{9}$ The Tax Equity and Fiscal Responsibility Act of 1982 included special requirements for top-heavy plans; The Tax Reform Act of 1986 introduced the definition of highly compensated employee, family aggregation rules, and other provisions that eliminated the tax qualification of smaller plans (Olsen and VanDerhei, 1997); The Omnibus Reconciliation Act of 1987 reduced the full funding limits for defined benefit plans from 100 percent of projected plan liability to the lesser of that value or 150 percent of benefits accrued to date. Basing funding limits on benefits already accrued means that funding contributions no longer include any provision for anticipated pay increases (McGill et al., 1996).

${ }^{10}$ The biggest increase in both absolute and relative costs of defined benefit versus defined contribution plans occurred in the late 1980s as plans adjusted to the Retirement Equity Act of 1984 and the Tax Reform Act of 1986 (Hustead, 1998); Kruse (1995) found that rising administrative costs contributed to the decline in defined benefit pension coverage over the period 1980-86.
} 
them more expensive. In particular, in response to the growing deficit at the PBGC, in early 2005 the Administration proposed to improve the agency’s finances by raising employer premiums and tightening funding requirements. ${ }^{11}$ The resulting legislation The Pension Protection Act of 2006 - dramatically shortened the period over which plan sponsors must eliminate funding shortfalls from 30 years to 7 years. The legislation also imposed more of a 'mark-to-market' framework than the previous set of rules, which allowed sponsors to smooth asset values. ${ }^{12}$ The 'mark-to-market' approach makes funding ratios more volatile, which generally makes the timing of contributions less predictable. The Pension Protection Act of 2006 also curtailed the use of credit balances - notional balances accumulated from previous years that could be used in lieu of cash contributions. ${ }^{13}$ This restriction puts additional financial stress on plan sponsors, especially those with poorly funded plans. ${ }^{14}$

Employers also faced likely reporting changes as the Financial Accounting Standards Board (FASB) undertook a comprehensive review to improve the transparency of pension accounting. In the wake of the first phase of that review, FASB required that the unfunded liabilities for pension and retiree health benefits appear on the firm's balance sheet. Phase two is likely to bring the U.S. accounting framework in line with international standards, which impose more of a 'mark-to-market' approach than the current U.S. accounting standard for private sector defined benefit pensions (FAS 87).

\footnotetext{
${ }^{11}$ This provision to raise the premiums for PBGC insurance was pulled out of the pension bill and included in the Deficit Reduction Act of 2005 that was signed into law on February 8, 2006. This legislation raised the premium from $\$ 19$ to $\$ 30$ per participant per year.

${ }^{12}$ Previous law allowed the value of assets to be smoothed over a 5-year period on a corridor of 80 to 120 percent of the market value of assets. The Pension Protection Act of 2006 reduced the smoothing period to 2 years and narrowed the corridor to 90 to 110 percent of the fair market value of assets.

${ }^{13}$ The Pension Protection Act of 2006 limits the use of credit balances in two ways. First, credit balances accumulate now at the actual rate of return of plan assets; and second, credit balances are subtracted from assets to estimate required contributions for "at risk" plans - plans that are identified as severely underfunded. Under ERISA, cash contributions that exceeded the minimum amount of contributions required by law were accumulated in a notional account. Every year, this notional account grew at the projected long-tem return of pension assets. Sponsors could then use the accumulated balances instead of cash contributions to meet the required amount of contributions.

${ }^{14}$ The concept behind credit balances was to allow sponsors to offset funding requirements in one year with amounts contributed in the past that were above the periodic contributions necessary to ensure proper funding. Credit balances, however, had perverse effects on poorly funded plans. Many sponsors of severely underfunded plans were able to avoid cash contributions for many years by using credit balances, even as the plans' assets fell and liabilities grew. For example, Bethlehem Steel and United Airlines used credit balances to avoid cash contributions for more than four years, even as their assets on hand were far below their estimated liabilities on a termination basis. See Belt (2005) and General Accountability Office (2005).
} 
The second phase will address a broad range of issues including the measurement of plan obligations, selection of actuarial assumptions, and the display of benefit costs on the company's income statement. Thus, an attempt by the FASB to provide a more realistic assessment of pension plan finances is likely to introduce substantially more volatility in the reported financial results of the sponsoring companies, further discouraging sponsorship of defined benefit pensions.

The changing nature of work and the labor force that diminished the desirability of long-term employment relationships, the rising costs of providing lifetime benefits, the financial hit from the 'perfect storm,' and legislative and accounting developments all conspired to make defined benefit plans look particularly unappealing to employers at the beginning of the $21^{\text {st }}$ century.

\section{The Early $21^{\text {st }}$ Century Was Always Going To Be Difficult}

The early $21^{\text {st }}$ century was always going to be a difficult time for sponsors of defined benefit plans. A series of regulatory changes, which took place in the 1980s and 1990s, ensured that sponsors of defined benefit plans would be very lean in terms of funding their ongoing pension commitments and would therefore require increased contributions. $^{15}$

\section{Reduction in Full Funding Limits}

The Employee Retirement Income Security Act of 1974 introduced both minimum funding requirements to ensure that employees' benefits were secure, and maximum limits on tax-deductible contributions to protect tax revenues. Originally the maximum funding limit was 100 percent of actuarial liability. ${ }^{16}$ Under the Omnibus Budget Reconciliation Act of 1987 (OBRA87), however, Congress significantly tightened the

\footnotetext{
${ }^{15}$ For a fuller discussion of these issues, see Munnell and Soto (2004), Schieber (2003), and Olsen and VanDerhei (1997).

${ }^{16}$ There are two definitions of pension liabilities used for funding purposes. Actuarial liability is an estimate of the benefits that workers have earned from their past service, calculated under assumptions set by the sponsor, including expected rates of salary increases and discount rates. Current liability is a measure of the benefits accrued to date using discount rates and mortality tables prescribed by law. See Pension Committee of the American Academy of Actuaries (2004).
} 
funding maximum by lowering the limit to the lesser of 100 percent of actuarial liability or 150 percent of current liability. ${ }^{17}$

The introduction of the " 150 percent of current liability" funding limit had a significant impact. ${ }^{18}$ Current liability is generally less than the actuarial liability because it does not include the effect of future salary increases on the value of pension rights already earned. ${ }^{19}$ Under the new limit, many sponsors found their fund assets exceeded 150 percent of their current liabilities and were prohibited from making any further tax deductible contributions to their defined benefit plans until their liabilities caught up with their assets. The fact that assets continued to grow as stock prices soared meant that many sponsors made no contributions for a significant period of time.

\section{The Impact of Reporting Requirements - FAS 87}

In 1985, FASB issued rules (The Statement of Financial Accounting Standards No. 87, Employers' Accounting for Pensions) requiring sponsors to account for accruing pension liabilities by a uniform method known as the "projected unit credit actuarial cost” method. Technically, FASB mandated the use of the projected unit credit only for reporting purposes, and firms could continue to use any of the six actuarial methods authorized under ERISA for funding. But sponsors appear to have either interpreted the FASB standard as an endorsement of the projected unit credit for funding as well as

\footnotetext{
${ }^{17}$ The Taxpayer Relief Act of 1997 increased the current liability full funding limit to 155 percent in 1999 and 2000, and 160 percent in 2001 and 2002. The Economic Growth and Tax Relief Reconciliation Act of 2001 accelerated the phase-out of the current liability funding limit (165 percent for 2002, 170 percent for 2003) and repealed the limit for plan years beginning in 2004. The Pension Protection Act of 2006 set the full funding limit as the 'funding target' (a concept similar to current liability), plus a cushion of 50 percent of the funding target, plus the amount by which the funding target would increase for increases in compensation.

${ }^{18}$ In calculating current liability, the interest rate used must fall within an acceptable range. The permissible range was between 90 and 105 percent of the weighted average yield on 30-year Treasury securities during the past four years. The Job Creation and Worker Assistance Act of 2002 increased the limit to 120 percent for 2002 and 2003 to reflect the elimination of the 30-year Treasury bond. The Pension Equity Funding Act of 2004 raised the rate to the long-term average of the corporate bond rate for 2004 and 2005. The Pension Protection Act of 2006 extended the use of the corporate bond rate for 2006. ${ }^{19}$ For example, if a plan provides 1.5 percent of final salary for each year of service, the employee with 10 years of service, who currently earns $\$ 40,000$, would have an accumulated vested benefit of $\$ 6,000$ per year. But if this employee is projected to have a final salary of $\$ 60,000$ by retirement, the same ten years of service would produce $\$ 9,000$ annually. The additional $\$ 3,000$ is included in the projected liability but not in the current liability. The actuarial liability, however, might be less than the current liability because the discount rate mandated by law for current liability purposes might be lower than the rate used by the sponsor for actuarial liability purposes.
} 
reporting or simply found it more convenient to use the same method for funding and reporting. As a result, a major shift occurred from the "entry age normal” method to the projected unit credit method for funding purposes (see Table 1).

The shift from entry-age normal cost to the projected unit credit method results in lower costs early in a worker's career and higher costs later. The reason is as follows. Under the entry age normal cost method, the actuary projects the contributions needed each year to finance an employee's benefits and then levels those contributions (either in absolute dollar amounts or as a percent of pay) over the entire period the employee is expected to participate in the plan. Under the projected unit credit method, contributions are made as benefits accrue, so they start low and increase each year. In addition, because the projected unit credit method allocates a larger portion of the required future contributions to normal cost than does the entry-age normal method, it usually yields a substantially smaller unfunded liability. This will reduce minimum required amortization payments. $^{20}$

The reason that the shift in actuarial methods had such a significant impact on funding is it reduced funding when the baby boom generation (those born between 1946 and 1964) were young workers (age 20 to 40 ). ${ }^{21}$ As the baby boomers aged, funding contributions became higher than they would have been under the entry-age normal cost method.

\section{"Reversion Tax"}

\footnotetext{
${ }^{20}$ A numerical example may help clarify the meaning of normal cost and unfunded liability under the two methods. Suppose an actuary calculates that the plan sponsor needs to contribute $\$ 15,000$ for a particular employee over the next five years. Under the projected unit credit method, the sponsor would fund pension payments as they accrue - say, $\$ 1,000$ in the first year, $\$ 2,000$ in the second year, $\$ 3,000$ in the third year, $\$ 4,000$ in the fourth year, and $\$ 5,000$ in the fifth year. Under the entry-age normal, the actuary would level the contributions over the five -year period so that the sponsor would pay a normal cost of $\$ 3,000$ per year. To determine the unfunded liability under the two methods, consider the status of the plans after two years of funding. Under the projected unit credit method, future normal cost payments would be $\$ 3,000, \$ 4,000$, and $\$ 5,000$ for a total of $\$ 12,000$. Since a total of $\$ 15,000$ will be needed and $\$ 12,000$ will come from normal cost contributions, a $\$ 3,000$ fund would be adequate to ensure future payments. If the fund were $\$ 4,000$, the actuary would declare a $\$ 1,000$ surplus. Under the entry-age normal method, the scheduled normal cost contributions of $\$ 3,000$ per year for the next three years would provide $\$ 9,000$. Since $\$ 15,000$ is required and $\$ 9,000$ will come from normal cost contributions, $\$ 6,000$ should be in the fund after two years. If the fund had only $\$ 4,000$, the actuary would declare an unfunded liability of $\$ 2,000$. Since the projected unit credit method allocates a larger portion of required future contributions to normal costs than the entry-age normal method, it usually yields a smaller actuarial unfunded liability.

${ }^{21}$ For a fuller discussion, see Watson Wyatt (1999).
} 
A third factor discouraging contributions was an excise tax on reversions first introduced in 1986. Up to that time, any reversion of excess assets to employers upon termination of the plan was simply included in taxable income in the year it was received. But in the mid-1980s corporate raiders were seen to be taking over companies and terminating their plans in order to get their hands on 'excess' pension assets. For example, in 1985 financier Ronald Perelman took over Revlon, closed down its pension plan and got control of its $\$ 100$ million surplus. ${ }^{22}$ In response to this raid and others, Congress enacted legislation in 1986 that introduced a 10-percent excise tax on reversions. Congress subsequently raised the rate to 15 percent in 1988 and to 50 percent in $1990 .^{23}$ While the reversion tax was not intended to limit contributions, some economists contend that it has severely restricted funding.

The notion is that projected liability consists of two parts - current liability and contingent benefits. ${ }^{24}$ Contingent benefits require the plan to stay in existence so that participants would have their existing credits applied to their salary at retirement rather than their current salary. Prior to 1986, the firm could accumulate assets to cover both current liability and the contingent benefits, yet retain the option of not paying the contingent benefits, by terminating the plan and reclaiming the 'excess assets.' After the reversion tax legislation, the payoff to canceling the contingent liability was severely restricted. Only by not funding the contingent benefits could the firm reduce its pension liabilities by the full amount. Of course, by not funding, the firm passes up the opportunity to make a tax-deductible contribution. ${ }^{25}$ Thus, legislation that was designed to protect pension promises by stopping terminations and reversions may have encouraged sponsors to shed the excess asset cushion it was designed to maintain.

\section{Cap on Compensation for Funding Purposes}

\footnotetext{
${ }^{22}$ Schultz (1999).

${ }^{23}$ Under the Omnibus Budget Reconciliation Act of 1990, the excise tax was lowered to 20 percent if part of the surplus is used to provide qualified pension benefits to participants. The 20-percent rate applies if the plan transfers 25 percent the surplus to a qualified replacement plan or if at least 20 percent of the surplus is used to increase the benefits of participants in the plan before it is terminated.

24 This discussion follows Ippolito (2001).

${ }^{25}$ Ippolito (2001) estimated that the reversion tax legislation cut excess assets by about $\$ 240$ billion as of 1995. If correct, this reduction is enormous given that total defined benefit assets in 1995 were $\$ 1,402$ billion.
} 
In an effort to limit the revenue losses from private pension plans, Congress imposed caps on compensation that could be considered in funding and contributing to tax qualified plans. The Tax Reform Act of 1986 set the limit at \$200,000 indexed for inflation. In 1993, when the limit had risen to $\$ 235,840$ due to adjustments for inflation, Congress in the Omnibus Reconciliation Act of 1993 (OBRA93) cut back the limit to $\$ 150,000$ beginning in 1994. Again, the limit was indexed for inflation. Although the legislation was designed to reduce benefits for the highly paid, it had the effect of limiting funding across the board. The reason is that the legislation does not permit sponsors to include anticipated increases in the compensation limit due to inflation adjustments for funding purposes.

The inability to consider future inflation adjustments meant that for the period 1994-2001, the effective cap was $\$ 150,000$. With projected salary growth of 4.5 percent, a 35-year-old earning $\$ 45,000$ would be expected to have a salary of $\$ 168,538$ at age 65 . This salary exceeded the cap by $\$ 18,538$, so the sponsor was required to reduce the funding below the amount required under current law. ${ }^{26}$ In 2001, Congress increased the compensation limit for funding purposes to $\$ 200,000$ beginning in 2002. Again, while the limit is indexed for inflation, the expected adjustments cannot be anticipated for funding purposes, once again limiting the ability of firms to fund projected benefits.

\section{Overall Impact}

The implication of the OBRA87 funding limit, the shift from the entry-age normal method to the projected unit credit method, the reversion tax, and the cap on compensation for funding purposes is that sponsors of defined benefit plans in the early $21^{\text {st }}$ century had done little to fund their ongoing pension commitments. Consistent data are available from 1979 through 2006 on the percentage of large plans in which assets exceed current liability (see Figure 4). The pattern reflects the story told above. In the wake of ERISA, funding improved steadily until the late 1980s. After the reversion tax and the full funding limit kicked in, the percent of plans with assets in excess of current

\footnotetext{
${ }^{26}$ The reduction was greater for those 35-year-olds earning higher salaries. The reduction would also be affected by the expected rate of inflation; the example cited above reflects the low inflation environment that the United States has enjoyed in recent years.
} 
liability declined. After 1996, the ratio rose once again presumably because of the enormous increase in stock prices. When the stock market bubble burst in 2000, the percent of plans with assets in excess of current liability fell back to 33 percent in 2004, a level not seen since 1980. The drop means that 67 percent of large plans did not have sufficient assets to cover even the current liability for their promised benefits if they were to terminate. ${ }^{27}$ By 2006, the percent of plans with assets in excess of current liability climbed back to 48 percent.

\section{The Freeze Becomes the Weapon of Choice}

Despite the 'perfect storm,' the changing funding and reporting requirements, and the predictable increase in required contributions, sponsors of healthy defined benefit plans did not terminate their plans. In fact, the liabilities in adequately funded plans that terminated fell to an all-time low in the 2000-2004 period, while those in terminated underfunded plans soared (see Table 2).

The challenge facing employers who want to terminate their plans in the early $21^{\text {st }}$ century is the requirement that they must immediately vest all benefits and either purchase annuities in the private sector to cover benefit commitments to workers and retirees or provide a lump-sum payment. ${ }^{28}$ If plans were underfunded - and many plans were underfunded in the wake of the 'perfect storm' - sponsors had to come up with additional money to cover benefits promised to workers and retirees. Moreover, even for plans that appear fully funded, the low interest rate environment at the beginning of the $21^{\text {st }}$ century made either the purchase of annuities or providing a lump sum extraordinarily expensive.

So instead of terminating their plans, plan sponsors have been instituting pension "freezes." These freezes mean that the number of active participants in the plan - those accruing benefits - will slowly dwindle as covered workers move to different jobs or retire. Without new entrants to the plan, these frozen plans will eventually terminate.

\footnotetext{
${ }^{27}$ Measuring liability on a termination basis generally produces a liability larger than current liability. See Pension Benefit Guaranty Corporation (2006).

${ }^{28}$ Generally, only companies operating under bankruptcy protection can transfer their liabilities to the Pension Benefit Guaranty Corporation.
} 
But the gradual pattern of termination offered by freezes has given sponsors time for the stock market to bounce back, for interest rates to rise, and for the firm to gradually put aside any additional funds required to cover promised benefits.

Legally, companies are free to freeze their pensions at any time to prevent any future pension accruals. The exception is plans for workers covered by collective bargaining agreements, where employers must negotiate any proposed change with the union. In all cases, employers can only make changes prospectively; they cannot take away pension benefits already earned. Companies with frozen plans are still required to meet the same funding and accounting standards as any firm that offers defined benefit plans.

In practice, freezes are done in a number of ways. Common to all is that new hires are kept out of the plan. Instead, they are offered an alternative arrangement such as a 401(k) plan. What happens to workers already participating in the plan is what defines the specific type of freeze - who is affected and by how much. ${ }^{29}$ The most extreme case is to stop all future benefit accruals to current participants - 'hard freezes.' Under hard freezes, benefits are literally frozen and additional years of service or salary increases will have no effect on retirement benefits. Nearly 85 percent of the freezes are hard freezes (see Figure 5). Another option is to allow employees to accrue additional benefits for salary increases but not for additional service. This is called a 'soft freeze,' but it is an option rarely exercised by plan sponsors. ${ }^{30}$ Lastly, plan sponsors may close the plan to new entrants but leave accruals of active participants unchanged - 'closed freezes.' Of the recent freezes, about 13 percent correspond to `closed freezes.’

\section{Financial Impact on the Employer}

\footnotetext{
${ }^{29}$ Sponsors can reduce accruals for some ("partial freeze”) or all (“total freeze”) of the plan’s active participants.

${ }^{30}$ An example will help clarify the difference between a hard and soft freeze. If the plan provides 1.5 percent of final salary for each year of service, workers with 20 years of service would be entitled to a benefit equal to 30 percent of final salary. The difference between a hard and soft freeze generally hinges on the definition of 'final salary.' Under a hard freeze, a 50-year-old employee earning \$50,000 would be entitled to $\$ 15,000$ (30 percent of $\$ 50,000$ ) a year at retirement. That is, 'final salary' is the worker's salary at the time of the freeze. Under a soft freeze, 'final salary' is generally the worker's salary at retirement instead of at age 50 . So, the 30 -percent credit would be applied to a salary of, say, $\$ 60,000$ instead of $\$ 50,000$. Thus, a soft freeze allows benefits to grow based on increases in earnings. Alternatively, companies exclude further salary increases, change the accrual factor, or use average rather than final salary for benefit calculations.
} 
A hard freeze generally has an immediate positive impact on the firm both in terms of funding requirements and financial reporting. ${ }^{31}$ First, because no further benefit accruals will occur, the plan's 'normal cost' - a component of the funding calculation generally drops to zero. The plan's current liability will decline each year as benefit commitments are paid off, further reducing funding contributions. Second, on the reporting side, analogous changes will be immediately evident. The computation of 'service cost' (a concept very close to 'normal cost' on the funding side) is eliminated. The FAS 87 computation of Pension Benefit Obligation (PBO) drops to the level of the Accumulated Benefit Obligation (ABO). The decrease in the $\mathrm{PBO}$ reduces the interest cost component of the FAS 87 calculation. ${ }^{32}$

\section{Financial Impact on the Employees}

For employees, the freeze of pension benefit accruals reduces retirement benefits. To offset these reductions, companies generally introduce a new 401(k) or enhance their existing defined contribution plan. For older workers, however, losses derived from a pension freeze are difficult to compensate. Table 3 shows the replacement rate - defined as pension benefits as a percent of earnings at age 62 - under a typical defined benefit plan that is frozen and replaced by a typical $401(\mathrm{k})$ plan. ${ }^{33}$ Note that the two plans are roughly equivalent in that the employee joining the 401(k) plan at 35 and the employee

\footnotetext{
${ }^{31}$ Sponsors of plans with unrecognized prior service cost or unrecognized actuarial losses may have to report an expense in the event of a plan freeze. See Tepfer (2006) and Latter (2006).

${ }^{32}$ A recent study, however, did not find that freezing a defined benefit plan produced a clear and immediate boost to market value. See Rubin (2007).

${ }^{33}$ Defined benefit plan amounts are based on 1.5 percent of the average of the last five salaries for each year of service, with a 5-percent discount for each year of benefit receipt before age 62. Calculations are based on a pattern of wage growth over a worker's career that is a composite of two factors. The first is the growth of nominal wages across the economy due to inflation and real wage growth. We use the projections of the Office of the Actuary of the Social Security Administration of 4.1 percent nominal wage growth, with inflation at 3 percent and thus real wage growth of 1.1 percent. The second factor is the rise and fall of earnings across a worker's career. We use an age-earnings profile based on career earnings profiles for males and females born between 1926 and 1965. In this profile, relative earnings reach a peak at age 47. After adding the economy-wide factors, real wages peak at age 51 and nominal wages at age 61 . To facilitate comparisons with data collected in the 2004 Survey of Consumer Finances (SCF), our simulation sets the salary at age 50 to $\$ 50,000$. This results in a salary of $\$ 18,500$ at age 30 and an ending salary of $\$ 58,000$ at age 62 - the median earnings for individuals age 62 who are covered by a $401(\mathrm{k})$, according to the SCF. The contribution rate for the $401(\mathrm{k})$ is 9 percent a year, with a 7.6 percent nominal rate of return on assets. We use inflation-adjusted values for pension wealth at age 55 to facilitate comparisons with pension wealth at age 62. For more details on the calculations and assumptions, see Munnell and Sundén (2004).
} 
who did not experience a freeze would both end up with about 45 percent of preretirement earnings at 62 (43 percent for the defined benefit plan and 44 percent for the 401(k) plan). ${ }^{34}$

Older employees have far more to lose from a pension freeze than their younger counterparts. An employee who joins the company's defined benefit plan at 35 would be entitled to a benefit equal to 43 percent of final earnings at age 62. If the sponsor freezes the plan when the employee is 50 and offers a $401(\mathrm{k})$, the replacement rate after the freeze is 28 percent, compared to 43 percent if the defined benefit plan had not been frozen. The relationship is not monotonic in age, however, because those who are about to reach age 62 have spent virtually all their lives under the defined benefit plan and are little affected by the freeze (see Table 3). ${ }^{35}$

In short, instead of terminating their plans, plan sponsors have made pension freezes the weapon of choice. These freezes generally have a positive financial impact for plan sponsors - lowering future contributions and improving the balance sheet. For workers, especially those in their 50s, pension freezes lower pension benefits, even for those with enhanced 401(k) plans.

\section{Which Companies Chose to Freeze Their Plans?}

In an attempt to identify factors that led companies to freeze their plans, the following section explores the relationship between the probability that a plan was frozen and characteristics of the plan, the firm, and the industry. The hypothesis is that plans most likely to be closed had the potential to hurt the financial statements of the firm, were relatively easy to close, and occurred in environments in which most of the firm's competitors relied on defined contribution plans.

The analysis focuses on the largest 5,000 firms in terms of revenue. The financial information comes from the 2005 Compustat data. The plan information comes primarily

\footnotetext{
${ }^{34}$ Even with enhanced 401(k) contribution rates, employees 50 and over lose from the freeze. See Munnell et al. (2006).

${ }^{35}$ These results are consistent with the findings of VanDerhei (2006) in which longer-tenure workers are more affected by pension freezes than younger workers.
} 
from the Department of Labor's Form 5500 for 2004. ${ }^{36}$ The 2004 data showed that of the 11,441 defined benefit plans, 1,133 had instituted a hard freeze. Subsequent information from press releases and sponsors' filings with the Securities and Exchange Commission (SEC) revealed another 158 plans that were frozen in the period 2005-2007. These plans were flagged as frozen in the 2004 Form 5500 data. For example, Verizon Communications reported in December 2005 that as of June 30, 2006, managers covered under the defined benefit plan would stop accruing benefits. This information was incorporated into Verizon’s 2004 Form 5500.

The next step was to merge the 2004 Form 5500 data (augmented with the freeze information from SEC filings and press releases) with the 2005 Compustat data. The construction of the sample is shown in Table 4. This process proved more difficult than anticipated. Merging by tax identification number produced only about half the firms and a quarter of the assets that Compustat reports for the top 5,000 firms. A tedious process of matching by hand brought the total to about 70 percent in terms of the number of firms that report having defined benefit plans in Compustat and to 52 percent in terms of assets (see Table 5). ${ }^{37}$ The percentages were higher for the Standard \& Poor's 500 - a subset of the larger sample. These merged data were then used to explore the probability of a plan being frozen (Appendix Table 1 lists the companies that froze plans with more than $\$ 100$ billion in assets).

The probability of a plan being frozen was assumed to depend on three factors: the potential damage that the plan could do to the firm's financial results, the cost to the firm of closing the plan, and the competitive environment in which the firm operated. Potential damage to the firm's financial results was measured by four variables. ${ }^{38}$

1) Credit balance as a percent of net income. This variable measures the amount accumulated in credit balances. The use of credit balances is limited by the

\footnotetext{
${ }^{36} 2004$ is the most recent year with complete data available from the Department of Labor. Plans that were identified as frozen in the partial 2005 data are also included in the analysis.

${ }^{37}$ The assets in the merged data, however, represent more than 80 percent of the total assets reported by single-employer plans in the 5500 Forms from 2004.

${ }^{38}$ We also tried the ratio of pension assets to firm assets to capture how big the plan is relative to the firm. The notion was that if the plan is large relative to the firm, fluctuations in assets or liabilities can have large consequences on the reported earnings of the firm. Thus, the greater the value of this ratio, the greater the probability the plan would be frozen. This variable however, was never statistically significant.
} 
Pension Protection Act of 2006. Companies with large accumulated balances are expected to respond by freezing their plans.

2) Plan is underfunded. This is a binary variable that identifies underfunded plans those with plan assets below current liability as reported in the 2004 Form $5500 .{ }^{39}$ Firms with underfunded plans are likely to experience a hit to their balance sheet under new FASB rules; underfunded plans might also require substantial cash contributions under the Pension Protection Act of 2006. On the other hand, it might be easier to freeze overfunded plans in that benefit commitments to workers could be more easily covered.

3) Difference between actuarial liability and current liability as a percent of market capitalization. This variable measures the financial gain from freezing the plan after a plan is hard frozen, the actuarial liability is reduced to the current liability ${ }^{40}$ Firms that have more to gain would be more likely to freeze their plans.

4) Credit risk. The credit risk variable is the numerical representation of the Standard and Poor's credit rating for the plan sponsor. A higher numerical score corresponds to a higher credit risk - a lower credit rating. ${ }^{41}$ As credit risk increases, firms would be inclined to freeze their plans in order to relieve financial pressure. $^{42}$

\footnotetext{
${ }^{39}$ Current liability is the full funding standard introduced in OBRA87. The IRS prescribes the interest rate and mortality assumptions to be used in the calculations. The value is disclosed in the plan's Form 5500 Schedule B. The interest rate used in this calculation was between 90 percent and 105 percent of the 30year Treasury bond over the past 4 years. The Job Creation and Worker Assistance Act of 2002 increased the limit to 120 percent for 2002 and 2003. The Pension Equity Funding Act of 2004 raised the rate to the long-term average of the corporate bond rate for 2004 and 2005. The Pension Protection Act of 2006 extended the use of the corporate bond rate for 2006.

${ }^{40}$ Actuarial liability is adjusted to account for the difference between the discount rate used by the sponsor for actuarial liability purposes and the discount rate used for current liability purposes. Actuarial liability was increased by 4 percent for each 25 basis point difference in discount rates (see Winklevoss 1993). An alternative specification, using the difference between the $\mathrm{PBO}$ and the $\mathrm{ABO}$ from Compustat, results in similar regression coefficients.

${ }^{41}$ Compustat codes the Standard and Poor's credit scores into numerical values, as follows: $\mathrm{AAA}=2, \mathrm{AA}+=4, \mathrm{AA}=5, \mathrm{AA}-=6, \mathrm{~A}+=7, \mathrm{~A}=8, \mathrm{~A}-=9, \mathrm{BBB}+=10, \mathrm{BBB}=11, \mathrm{BBB}-=12, \mathrm{BB}+=13, \mathrm{BB}=14$, $\mathrm{BB}-=15, \mathrm{~B}+=16, \mathrm{~B}=17, \mathrm{~B}-=18, \mathrm{CCC}+=19, \mathrm{CCC} / \mathrm{CC}=20,23, \mathrm{C}=21,24, \mathrm{D} / \mathrm{SD}=27,29,90$.

${ }^{42}$ Sponsors with high credit risk (speculative grade) are also more likely to have lower funding levels, higher discount rate assumptions, and generally represent greater risks to the PBGC. See Government Accountability Office (2005).
} 
Three variables were included to gauge how easy or difficult it would be for a firm to freeze a plan:

1) Active participants to total firm employees. This ratio measures how much of the firm's workforce is covered by the plan. Plans that cover the whole labor force might be more difficult to freeze than smaller plans that cover only a portion of the employees.

2) Collectively bargained. Since the employer must negotiate with the union before freezing such a plan, plans that are collectively bargained are much more difficult to freeze.

3) Hybrid plans. The effect of having switched to a hybrid plan is uncertain. Firms that have hybrid plans have already moved away from traditional defined benefit commitments, making a change to a $401(\mathrm{k})$ plan less dramatic. On the other hand, firms that have already switched to a hybrid plan might not need to freeze their plan to deal with uncertainty or risk.

Finally, four variables were included to represent the competitive position of the firm.

1) Ratio of retirees to total participants. This variable measures the age of the plan, and the extent to which, in underfunded plans, current firm income must go to provide benefits for past workers. A high ratio of retirees to participants is a sign that defined benefit plans might be inappropriate for the business model of the firm - the bulk of the current labor force might be outsourced or not covered by the plan. ${ }^{43}$ The expected impact would be assumed to be positive.

2) Market capitalization of the firm. The recent wave of pension freezes includes well-known firms with large market capitalization. These firms are subject to global competitive pressures. The expected impact would be assumed to be positive.

\footnotetext{
${ }^{43}$ In addition, plans with a high ratio of retirees to total participants are likely to experience an increase in contributions under the new funding rules. The Pension Protection Act of 2006 establishes the use of a yield curve of high grade corporate bonds to discount pension liability. Older plans, with liabilities of shorter duration, will be required to use lower discount rates - short-term rates are generally lower than long-term rates. Lower discount rates produce larger pension liability and higher required contributions.
} 
3) Percent of competitors with defined contribution plan only. ${ }^{44}$ The greater the proportion of other firms in the industry with defined contribution plans instead of defined benefit plans, the greater the probability that a plan will be frozen.

4) Research and development intensity in the industry. The R\&D intensity is measured as the median ratio of $R \& D$ expenditures to sales for each industry from Compustat. Industries with substantial R\&D intensity are likely to benefit the most from the talent retention features of defined benefit plans. The expected impact of industry R\&D intensity would be expected to be negative.

5) Industry dummies. These were designed to capture not only the prevalence of defined contribution plans and R\&D intensity, but competitive pressures and other factors that could lead to plan freezes.

The descriptive statistics of the sample are presented in Table 6. More than 15 percent of plans experience some type of freeze. The majority of the freezes are hard freezes - 13 percent of the sample. Financial considerations are related to the freeze decision. Frozen plans have lower median credit balances, but a higher mean - a few companies that have accumulated substantial credit balances decided to freeze their plans. Frozen plans have lower funding ratios and higher credit risk. The cost to the firm of closing the plan is also relevant. Frozen plans cover fewer employees, are less likely to be collectively bargained, and are less likely to be hybrid. Finally, the competitive environment is also an important factor for the decision to freeze a plan. Frozen plans have a higher ratio of retired to total participants, and are likely to be in industries where defined contribution plans are more prevalent.

A regression model is estimated, and the results are presented in Table 7. Given the binary nature of the dependent variable - 1 if a plan is frozen, 0 otherwise - the model is estimated using a probit. The values reported in the table are the change in the probability of a plan being frozen given a one-unit change in a continuous variable or the

\footnotetext{
${ }^{44}$ This variable is measured as $1-\mathrm{P}(\mathrm{DBi})$, where $\mathrm{P}(\mathrm{DBi})$ is the proportion of companies with defined benefit plans for industry i, using the top 5,000 companies in revenues from Compustat. Eighteen industry categories are used: agriculture, mining and construction; apparel and textile products; chemicals and allied products; fabricated metal products; food and tobacco products; machinery and computer equip.; motor vehicles; primary metals; rubber and plastics; other manufacturing; air transportation; other transportation; public utilities; wholesale trade; retail trade; finance, insurance and real estate; services; and missing industry.
} 
shift in a dichotomous variable from zero to one. For example, a one-unit increase in the credit risk of the firm increases the probability of freezing a plan by 1.18 percentage points. If the plan is collectively bargained, the probability of freezing it declines by 7.18 percentage points, all else equal. The results are shown for two measures of freezes - any type of freeze and hard freeze only. The variables enter the equations with the expected sign and are generally statistically significant.

In terms of financial factors, the results suggest that credit balances increase the probability of freezing a plan. Sponsors with credit balances might experience a substantial increase in contributions under the funding rules of the Pension Protection Act of 2006. Without the ability to use credit balances to offset minimum required contributions, plan sponsors are exposed to sudden increases in contributions, which could increase the volatility of earnings. ${ }^{45}$ The results indicate that plans with large credit balances are likely to freeze, although the coefficients are marginally significant.

The funding variable suggests that underfunded plans are being frozen. Sponsors of these plans will see a significant increase in contributions under the Pension Protection Act of 2006 and will experience a hit to their balance sheet and earnings statements under new FASB rules. ${ }^{46}$ Employers would find it particularly difficult to terminate these plans, since they would have to raise cash to pay off benefit commitments, so a freeze is a logical way to head towards termination. The funding-ratio variable appears to be more important in the case of hard freezes than soft ones. This result makes sense in that sponsors of underfunded plans would probably like to avoid any further accrual of benefits, while employers with adequately funded plans have the luxury to avoid such an abrupt action and adopt a soft freeze.

\footnotetext{
${ }^{45}$ Although the limits on the use of credit balances might increase the volatility of contributions, other features of the Pension Protection Act of 2006 could make contributions less volatile than previous law. Specifically, the additional required contributions for "at risk" plans are not as large as before, and the full funding limitations are less binding. See Warshawsky (2007).

${ }^{46}$ First, the Pension Protection Act of 2006 requires annual contributions of about 15 percent of the unfunded liability. These requirements mean that many sponsors of plans that are currently near or above 90 percent funded - which were not required to make additional contributions under previous law - would experience higher level of contributions. More specifically, The Pension Protection Act of 2006 requires plans to amortize unfunded liabilities within 7 years; previous law required sponsors to amortize unfunded liabilities within 3 to 7 years, but it exempted plans with funding ratios of above 90 percent. Second, the FASB rules required the unfunded liability to be reported on the balance sheet.
} 
The financial health of the firm also appears to be driving hard freezes. An increase in the scale of risk - going from $\mathrm{BBB}+$ to $\mathrm{BBB}$, for example - increases the probability of freezing by more than 1 percentage point. The financial gains from freezing a plan, however, do not seem to be motivating freezes. The coefficient for the difference between actuarial and current liability is not statistically significant under the proposed specifications.

In terms of the difficulty of freezing the plan, employers appear to be following the path of least resistance. Plans that cover relatively few employees are more likely to be frozen and collectively bargained plans are less likely, at least in the short term. Freezing plans for white collar workers, however, may mean a freeze in the union plans down the road. In fact, press releases from some of the firms in the process of freezing their plans indicate the desire to freeze union plans upon negotiation with the union. ${ }^{47}$

Finally, the nature of the industry appears to matter. Firms with large legacy costs, as measured by the ratio of retired participants to total participants, are more likely to freeze their plans. Scale effects exist: firms with large market capitalization are more likely to freeze their plans. If defined contribution plans are prevalent in the industry, employers are more likely to freeze their defined benefit plans. Industries with high R\&D intensity are less likely to freeze their plans. Other industry characteristics are also most likely relevant, so a second set of equations were run with an indicator variable with broad industry categories. Adding the industry variables enhances the explanatory value of the equations, but does not affect the coefficients on any of the other variables in the equation.

\section{Implications for the Future of Defined Benefit Plans}

The question is what these results imply for the future of defined benefit plans. The news is that a number of large healthy employers want to get out of sponsoring

\footnotetext{
${ }^{47}$ Met-Pro, for example, announced the freeze of its defined benefit plan for non-union hourly employees and the intent "to seek a similar freeze for its remaining workforce when their collective bargaining agreement is renegotiated next year." See Met-Pro Corp. (2006). When Remington Arms froze their nonunion plan, one of the union representatives stated that changes to the union plan would be later negotiated with the union. See Ackerman (2006).
} 
defined benefit plans. ${ }^{48}$ This trend most likely reflects the decline in long-term employee-employer relationships, the burden of funding plans that have not adequately prepared for projected pension liabilities, the financial hit created by the 'perfect storm,' changes in funding requirements under the Pension Protection Act, and the potential uncertainty with regard to earnings statements in the wake of expected FASB requirements.

Overall results. In terms of the variables in the equations, the results imply that plans where credit balances are high relative to income, legacy costs are substantial and funding ratios are low have a higher probability of being frozen. That makes sense in that plans with these characteristics are likely to have the most impact on future earnings under FASB's expected reporting requirements. It is reasonable to expect more plans with these characteristics to freeze in the future. (Appendix Table 2 lists the companies that are likely to freeze next according to the probit results). ${ }^{49}$

Implications for cash balance plans. One of the more interesting findings comes from an insignificant result. The coefficient associated with the variable 'hybrid plan' is negative but not statistically significant. Hybrid plans are generally cash balance plans. ${ }^{50}$ An obvious question is whether converting a traditional defined benefit plan to a cash balance plan is the first step toward termination. Termination may not have been an appealing option in the 1990s when most of the conversions occurred, because sponsors would have had to pay the 50-percent reversion tax. But the 'perfect storm' eliminated most of those surpluses, so the barrier to termination disappeared. The results, however, suggest that having a hybrid plan does not affect the probability of freezing a plan.

The insignificant coefficient of hybrid plans appears puzzling. Hybrid plans eliminate several aspects of traditional plans that employers find burdensome. Benefit accumulations are not back-loaded but rather occur evenly over the employee's worklife, which fits most employers' personnel objectives. They are easier to explain to employees, which makes them a more effective recruitment tool. They remove most of

\footnotetext{
${ }^{48}$ For example, IBM, Citigroup, and Hershey Foods have frozen their plans despite having credit ratings of A+ (see Appendix Table 1). The list of companies likely to freeze next also includes some large healthy firms: Bank of America, Allstate Insurance, and Equifax (see Appendix Table 2).

${ }^{49}$ The list of companies likely to freeze next includes companies with a predicted probability of freeze greater than the $75^{\text {th }}$ percentile of the predicted probability for plans that are already frozen (0.3404).

${ }^{50}$ In the sample, about 97 percent of the plans identified as hybrids are cash balance plans.
} 
the investment risk in that the plans promise a well-defined rate of return, usually linked to a Treasury security. And cash balance plans eliminate the demographic and inflation risk associated with the provision of annuities. ${ }^{51}$ Yet, the insignificant coefficient on the hybrid plan variable suggests that cash balance plans might not prevent plan freezes.

A possible explanation of why some cash balance plans have been frozen might come from the legal and regulatory uncertainty that has surrounded these plans. Until very recently, cash balance plans were the target of extensive litigation which might have influenced the decision to freeze some of these plans. The Pension Protection Act of 2006 resolved the uncertainty for future conversions by explicitly making cash balance plans legal; court decisions have also ruled in favor of plans converted prior to the Act. ${ }^{52}$ The question is whether sponsors can live with cash balance plans now that the legal uncertainty is resolved. Recent developments indicate that some sponsors might decide to convert their traditional plan to a cash balance rather than freezing it. Dow Chemical, for example, recently announced a plan conversion. ${ }^{53}$

The fact that firms might be able to live with cash balance plans suggests that ultimately defined benefit plans could possibly look more like old-fashioned money purchase plans - defined contribution plans with required employer contributions where employees might be given the right to direct investments - than like the current 401(k) plans. This would certainly represent an improvement to the U.S. retirement income system.

Financial incentives. Another interesting finding rests with another statistically insignificant result. Previous analyses of employers moving away from traditional defined benefit plans - namely, the conversion to cash balance plans in the 1990s -

\footnotetext{
${ }^{51}$ While cash balance plans are not perfect, they are significantly better structured than $401(\mathrm{k})$ plans. They relieve employees of the participation, contribution, and investment decisions that employees must make with 401(k) plans. Participation is automatic, and the employer makes the contributions on behalf of the employee and Guaranty Corporations the return. At the same time, for the mobile employee, cash balance plans offer the same advantage as 401(k) plans in that benefits accrue at a steady rate over the employee's working life, rather than being related to final pay. Unfortunately, cash balance plans pay lump-sum benefits both at termination and at retirement, which expose individuals to the risk of outliving their pension accumulations.

${ }^{52}$ See Cooper, Kathi, et al. v. The IBM Personal Pension Plan and IBM Corporation (2006); the Supreme Court later declined to review the decision. Some argue, however, that the legal uncertainty surrounding cash balance plans has not been completely resolved for plans converted prior to the passing of the Pension Protection Act of 2006 (Zelinsky 2007).

${ }^{53}$ See Dow Chemical (2007).
} 
concluded that labor force considerations, not saving money, was the prime motivation. One study argued that in the tight labor market of the 1990s employers wanted to get rid

of the early retirement incentives embedded in most traditional defined benefit plans. ${ }^{54}$ Another concluded that most of the conversions had taken place in tight labor markets and could be best viewed as an effort to better compensate a more mobile labor force. ${ }^{55}$ Because these earlier studies suggested financial savings were not of primary importance in conversions to cash balance plans, the expectation was that variables representing financial savings did not belong in the estimated equations for pension freezes.

The data are available, however, on the cost savings that could be achieved from a hard freeze. A hard freeze immediately reduces the firm's liability from a projected benefit concept to an accrued benefit measure. The difference between the actuarial liability and the current liability (the Form 5500 measures) relative to assets was added to the probit equations at the plan level reported above. Regardless of the specification of the equation, the coefficients were never statistically significant. Additional equations were estimated at the firm level, and the difference between the projected benefit obligation and the accrued benefit obligation (the FAS 87 measures) relative to assets was included. Again, the coefficients were not statistically significant. Thus, short-term cost savings do not appear to be the motivation. This seems reasonable given that most companies enhance their 401(k) provisions when they freeze their defined benefit plans.

Employers themselves do acknowledge that long-term cost savings are a major objective of freezing their plans. ${ }^{56}$ However, this objective ranks below the desire to reduce cost volatility, which dominates every survey as the prime objective.

\section{Conclusion}

Defined benefit plans in the private sector are on the decline. Although they still cover about 21 million workers and pay benefits to 23 million retires, the proportion of the workforce covered by these plans has dropped by more than half (from more than 40 percent to less than 20 percent) since 1980.

\footnotetext{
${ }^{54}$ See Clark and Schieber (2000) and Schieber (2003).

${ }^{55}$ See Coronado and Copeland (2004).

${ }^{56}$ Merrill Lynch (2006).
} 
The early $21^{\text {st }}$ century produced an uptick in the pace of decline driven by the financially devastating impact of the 'perfect storm,' legislation that will require underfunded plans to increase their contributions, and accounting changes that will force fluctuations in pension finance onto the earnings statement.

The Pension Protection Act of 2006 represents the most significant change in pension regulation since ERISA. The new funding rules, which take effect in 2008, significantly reduce the leeway that companies have in making contributions to their plans. Plans must now be 100 percent funded, and most sponsors of underfunded plans have only seven years to pay off any existing shortfall. Moreover, sponsors will have less ability to smooth the value of assets or liabilities, making cash contributions significantly more volatile.

At the same time, FASB has instituted the first step of a two-step pension reform project, by requiring sponsors to show pension surpluses or deficits directly on the balance sheet. This change could seriously cut into shareholder equity and introduces volatility to the balance sheet. In the second step, expected in the next three years, FASB is expected to require companies to mark-to-market the value of pension assets and liabilities, eliminating the smoothing available under current rules. Given the enormous volatility in the stock and bond markets in recent years, marking-to-market could introduce significant additional volatility in reported earnings.

Such volatility is not acceptable to corporate managers, and may in large part explain why large healthy companies have taken steps to end their defined benefit plans. The fact that these steps took the form of freezes rather than terminations simply reflects the fact that with underfunding caused by the perfect storm and very low interest rates, firms could not afford to pay off all their liabilities immediately. Freezing their plans provided the option to terminate gradually. As funding levels improve, terminations are likely to replace freezes.

The forces in place suggest that companies will continue to move away from defined benefit plans. McKinsey \& Company (2007) suggests that as much as 75 percent of private sector defined benefit assets will be in frozen or terminated status by 2012 . When the United Kingdom adopted regulatory and accounting rules similar to those recently adopted in the United States, the percent of assets in terminated or frozen status 
soared from 35 percent in 1998 to 70 percent in 2006. It may well be that the only defined benefit plans left standing in the private sector five years from now will be cash balance plans or some other form of hybrid. The age of the traditional defined benefit plan seems to be over. 


\section{References}

Aaronson, Stephanie and Julia Coronado. 2005. “Are Firms or Workers Behind the Shift Away from DB Pension Plans?” Finance and Economics Discussion Series No. 2005-17, Federal Reserve Board of Governors, April 2005.

Ackerman, Bryon. 2006. "Remington Freezing Pension Plans for Non-Union Employees.” Utica Observer-Dispatch. October 11.

Andrews, Emily S.. 1992. “The Growth and Distribution of 401(k) Plans,” in Trends in Pensions 1992, edited by John Turner and Daniel Beller. Washington, DC: U.S. Department of Labor.

Belt, Bradley D. 2005. “Testimony Before the Subcommittee on Aviation, Committee on Transportation \& Infrastructure.” June 22, 2005.

Clark, Robert L. and Sylvester J. Schieber. 2000. An Empirical Analysis of the Transformation to Hybrid pension Plans in the United States.” Washington, DC: The Brookings Institution.

Coronado, Julia Lynn and Philip C. Copeland, 2004. "Cash balance pension plan conversions and the new economy. Journal of Pension Economics and Finance, Cambridge University Press, vol. 3(3), pages 297-314, November.

Cooper, Kathi, et al. v. The IBM Personal Pension Plan and IBM Corporation. 2006. 99829-GPM. Appeal from the United States District Court for the Southern District of Illinois. G. Patrick Murphy, Chief Judge. Argued February 16, 2006-Decided August 7, 2006.

Dow Chemical. 2007. Dow Looks to Future with New U.S. Retirement Program Company prepares to attract the best talent with innovative benefits plan. Press Release. Midland, MI - July 17, 2007.

Gustman, Alan L. and Thomas L. Steinmeier. 1992. “The Stampede Toward Defined Contribution Pension Plan: Fact or Fiction?” Industrial Relations 31(2): 361-69.

Hustead, Edwin C. 1998. “Trends in Retirement Income Plan Administrative Expenses.” In Living with Defined Contribution Plans: Remaking Responsibility, edited by Olivia S. Mitchell and Sylvester J. Scheiber, 166-77. Philadelphia, PA: University of Pennsylvania Press for the Pension Research Council.

Ippolito, Richard A. 1995. “Toward Explaining the Growth of Defined Contribution Plans.” Industrial Relations. 34(1): 1-20.

Ippolito, Richard A. 1999. "The New Pension Economics: Defined Contribution Plans and Sorting." Paper prepared for EBRI policy forum on the next twenty-five years of ERISA. 
Ippolito, Richard A. 2001. "Reversion Taxes, Contingent Benefits, and the Decline in Pension Funding.” Journal of Law and Economics. vol. XLIV (April).

Kruse, Douglas. 1995. “Pension substitution in the 1980's: Why the shift toward Defined Contribution Plans?” Industrial Relations. 34(2):218-241.

Latter, Gordon J. 2006. “The Trend to Freeze Pension Plans.” Pensions and Endowments. 13. Merrill Lynch. June.

McGill, Dan M. Kyle N. Brown, John J. Haley, and Sylvester Schieber. 1996. Fundamentals of Private Pensions. Philadelphia, PA: University of Pennsylvania Press.

McKinsey \& Company. 2007. "The Coming Shakeout in the Defined Benefit Market.” New York: NY.

Merrill Lynch. 2006. “The Trend to Freeze Pension Plans.” Pensions and Endowments 13.

Met-Pro Corporation. 2006. "Met-Pro Corporation Announces Pension Plan Changes.” Press Release. November 1, 2006.

Munnell, Alicia H. 1982. The Economics of Private Pensions. Washington, DC: The Brookings Institution.

Munnell, Alicia H. and Annika Sundén. 2004. Coming Up Short: The Challenge of 401(k) Plans. Washington, DC: The Brookings Institution Press.

Munnell, Alicia H. and Mauricio Soto. 2004. The Outlook for Pension Contributions and Profits in the US.” Journal of Pension Economics and Finance, Cambridge University Press, vol. 3(01), pages 77-97, May.

Munnell, Alicia H., Francesca Golub-Sass, Mauricio Soto and Francis Vitagliano. 2006. "Why Are Healthy Employers Freezing Their Pensions?” Issue in Brief 44. Chestnut Hill, MA: Center for Retirement Research at Boston College.

Olsen, Kelly and Jack VanDerhei. 1997. "Defined Contribution Plan Dominance Grows Across Sectors and Employer Sizes, While Mega Defined Benefit Plans Remain Strong: Where We Are and Where We Are Going.” EBRI Special Report SR-33. October.

Papke, Leslie, Mitchell Petersen, and James Poterba. 1996. “Do 401(k) Plans Replace Other Employer Provided Pensions?” In Advances in the Economics of Aging, edited by David A. Wise, 219-40. University of Chicago Press. 
Pension Benefit Guaranty Corporation. 2007. Personal Communication with the Office of General Counsel, Disclosure Division. Washington, DC.

Pension Benefit Guaranty Corporation. 2006. “Pension Insurance Data Book 2005.” Pension Benefit Guaranty Corporation. Number 10. Summer.

Pension Committee of the American Academy of Actuaries. 2004. "Fundamentals of Current Pension Funding and Accounting for Private Sector Pension Plans.” American Academy of Actuaries. July.

Rubin, Jordan. 2007. “The Impact of Pension Freezes on Firm Value.” Wharton Research Scholars Journal. University of Pennsylvania.

Sass, Steven A. 1997. The Promise of Private Pensions. Cambridge, MA: Harvard University Press.

Schieber, Sylvester. 2003. “The Shift to Hybrid Pensions by U.S. Employers: An Empirical Analysis of Actual Plan Conversions. Pension research Council Working Paper WP 2003-23.

Schultz, Ellen E..1999. “Pension Terminations: “80s Replay.” Wall Street Journal. June 15, p.C1.

Tepfer, Hal. 2006. “Step into the freeze: A DB Pension Plan Primer.” Workspan.

U.S. Bureau of the Census. 1994. General Report on Industrial Organization 19721992. Washington, DC: U.S. Government Printing Office.

U.S. Bureau of the Census. 2005. Statistical Abstract of the United States: 2006 (125th Edition). Washington, DC.

U.S. Department of Labor, Employee Benefits Security Administration, Office of Policy and Research. 2004. "Abstract of 1999 Form 5500 Annual Reports." Private Pension Plan Bulletin 12. Washington DC: U.S. Government Printing Office. Available at: http://www.dol.gov/ebsa/PDF/1999pensionplanbulletin.pdf.

U.S. Department of Labor, Employee Benefits Security Administration, Office of Participant Assistance. 2002-2005. Annual Return/Report Form 5500 Series for Plan Years 1990-2003. Washington DC: U.S. Government Printing Office.

U.S. Department of Treasury. 2007. "EP Determination Letter Resource Guide - Do I Need to File for a Determination Letter for my Retirement Plan?” http://www.irs.gov/retirement/article/0,,id=128038,00.html

U.S. General Accountability Office. 2005. Recent Experiences of Large 
Defined Benefit Plans Illustrate Weaknesses in Funding Rules. GAO-05-294. Washington, DC: U.S. Government Printing Office.

VanDerhei, Jack. 2006. "Defined Benefit Plan Freezes: Who's Affected, How Much, and Replacing Lost Accruals” Working Paper No. 291. Washington, DC: Employee Benefit Research Institute.

Warshawsky, Mark J. 1995. "Determinants of Pension Plan Formation and Termination.” Benefits Quarterly. Fourth Quarter: 71-80.

Warshawsky, Mark J. 2007. "The New Pension Law and Defined Benefit Plans: A Surprisingly Good Match.” 2007. Working Paper. PRC WP2007-06. Pension Research Council Working Paper.

Watson Wyatt 1986, 1992, 1998, 2001, 2006. Survey of Actuarial Assumptions and Funding: Pension Plans with 1,000 or More Participants. New York, NY.

Watson Wyatt. 1999, "The Unfolding of a Predictable Surprise: A Comprehensive Analysis of the Shift from Traditional Pensions to Hybrid Plans."

Winklevoss, Howard E. 1993. Pension Mathematics with Numerical Illustrations. University of Pennsylvania Press.

Zelinsky, Edward A. 2007. "Cooper v. IBM Personal Pension Plan: A Critique." New York University Review of Employee Benefits and Executive Compensation. 
Table 1. Percent of Large Pension Plans Using Alternative Actuarial Methods, 19762006

\begin{tabular}{|l|r|r|r|r|r|r|r|}
\hline Actuarial cost method & 1976 & 1981 & 1986 & 1991 & 1996 & 2002 & 2006 \\
\hline Projected unit credit & - & & - & 28 & 54 & 54 & 66 \\
\hline Entry age normal & 57 & 53 & 40 & 31 & 31 & 24 & 19 \\
\hline Other & 43 & 47 & 32 & 15 & 15 & 10 & 7 \\
\hline
\end{tabular}

Source: Watson Wyatt Worldwide, 2006, 2003, 1998, 1992, 1986. Survey of Actuarial Assumptions and Funding: Pension Plans with 1,000 or More Participants. 
Table 2. Terminations of Single-Employer Plans Reported to the PBGC

\begin{tabular}{|l|r|r|r|r|}
\hline \multirow{2}{*}{ Year } & \multicolumn{2}{|c|}{ Adequately funded plans } & \multicolumn{2}{c|}{ Underfunded plans } \\
\cline { 2 - 4 } & Number & $\begin{array}{c}\text { Liabilities } \\
\text { (billions) }\end{array}$ & \multicolumn{2}{c|}{$\begin{array}{c}\text { Lumber } \\
\text { (billiobilities }\end{array}$} \\
\hline $1985-1989$ & 48,519 & 44.3 & 537 & 2.4 \\
\hline $1990-1994$ & 36,340 & 28.1 & 692 & 5.1 \\
\hline $1995-1999$ & 15,620 & 20.9 & 438 & 2.2 \\
\hline $2000-2004$ & 6,969 & 13.0 & 595 & 31.9 \\
\hline
\end{tabular}

Source: Pension Benefit Guaranty Corporation (2007). 
Table 3. Total Replacement Rate at 62 for Worker Who Entered at 35, by Age at which Defined Benefit Plan Is Frozen and Replaced with a 401(k)

\begin{tabular}{|l|c|c|c|c|c|c|}
\hline \multirow{2}{*}{ Source } & \multicolumn{6}{|c|}{ Age at which defined benefit plan is frozen and replaced with a $401(\mathrm{k})$} \\
\cline { 2 - 7 } & 35 & 40 & 45 & 50 & 55 & 62 \\
\hline Defined benefit plan & $0 \%$ & $3 \%$ & $7 \%$ & $13 \%$ & $20 \%$ & $43 \%$ \\
\hline $401(\mathrm{k})$ Plan & 44 & 33 & 23 & 15 & 8 & 0 \\
\hline Total & 44 & 36 & 30 & 28 & 28 & 43 \\
\hline
\end{tabular}

Source: Authors’ calculations. 
Table 4. Construction of Merged Form 5500/Compustat Sample

\begin{tabular}{|l|r|}
\hline \multicolumn{2}{|c|}{5500 Data: 2004} \\
\hline Defined benefit plans & 11,441 \\
\hline \multicolumn{2}{|c|}{ releases } \\
\hline \multicolumn{2}{|c|}{ Freezes: 2005-07 from SEC filings and press } \\
\hline Total freezes & 1,133 \\
\hline Hard frozen & 101 \\
\hline Soft frozen & 10 \\
\hline Closed to new entrants & 47 \\
\hline \multicolumn{2}{|c|}{} \\
\hline Top firms in revenues & 5,000 \\
\hline Firms with DB plans & 1,654 \\
\hline \multicolumn{2}{|c|}{ Merged 5500-Compustat Data } \\
\hline Defined benefit plans & 2005 \\
\hline Frozen, any type & 1,896 \\
\hline Hard frozen & 243 \\
\hline \multicolumn{2}{|c|}{} \\
\hline Firms & 1,139 \\
\hline At least one plan frozen & 179 \\
\hline At least one plan hard frozen & \\
\hline
\end{tabular}

Source: Authors' calculations 
Table 5. Comparison of Merged Sample with Compustat Information for S\&P 500 and for Top 5,000 Firms

\begin{tabular}{|l|l|l|l|l|l|l|}
\hline \multirow{2}{*}{ Item } & \multicolumn{3}{|c|}{ Standard \& Poor 500 } & \multicolumn{3}{c|}{ Top 5,000 Firms } \\
\cline { 2 - 7 } & Compustat & $\begin{array}{l}\text { Merger } \\
\text { Process }\end{array}$ & Percent & Compustat & $\begin{array}{l}\text { Merger } \\
\text { Process }\end{array}$ & Percent \\
\hline Firms with DB plans & 342 & 335 & 98.0 & 1,654 & 1,139 & 68.9 \\
\hline Assets in DB plans $^{1}$ & $\$ 1,321 \mathrm{~B}$ & $\$ 973 \mathrm{~B}$ & 73.6 & $\$ 2,339 \mathrm{~B}$ & $\$ 1,208 \mathrm{~B}$ & 51.6 \\
\hline Number of DB plans $^{2}$ & NA & 667 & NA & NA & 1,896 & NA \\
\hline
\end{tabular}

1. Our estimate of total assets in defined benefit plans from the 2004 Form 5500 is $\$ 2,018$ billion $(\$ 1,493$ from single-employer plans and $\$ 525$ from multiemployer or multiple employer plans); the estimate from the Federal Reserve's Flow of Funds is \$2,132 billion.

2. Compustat does not provide any information on the number of plans.

Source: Authors’ calculations. 
Table 6. Descriptive Statistics of Sample

Sample size (plans) 1,802

\begin{tabular}{|c|c|c|c|c|c|c|c|c|c|}
\hline Any freeze & 278 & $15.4 \%$ & & & & & & & \\
\hline Hard freeze & 235 & $13.0 \%$ & & & & & & & \\
\hline Any freeze & \multicolumn{4}{|c|}{ Not Frozen } & \multicolumn{5}{|c|}{ Frozen } \\
\hline 1) Financial considerations & Mean & p25 & p50 & p75 & Mean & p25 & $\mathrm{p} 50$ & p75 & \\
\hline Credit balance to net income & $29.1 \%$ & $0.1 \%$ & $3.4 \%$ & $26.5 \%$ & $35.4 \%$ & $0.0 \%$ & $1.6 \%$ & $41.4 \%$ & \\
\hline Underfunded plan & $50.7 \%$ & $0.0 \%$ & $100.0 \%$ & $100.0 \%$ & $63.3 \%$ & $0.0 \%$ & $100.0 \%$ & $100.0 \%$ & $* * *$ \\
\hline (Actuarial liab. - current liab.)/ market caf & $14.4 \%$ & $0.0 \%$ & $0.2 \%$ & $1.4 \%$ & $5.3 \%$ & $0.0 \%$ & $0.0 \%$ & $0.5 \%$ & \\
\hline Credit risk & $\mathrm{BB}+$ & $\mathrm{BBB}+$ & BBB- & BB- & $\mathrm{BB}$ & BBB & $\mathrm{BB}$ & $\mathrm{B}+$ & $* * *$ \\
\hline \multicolumn{10}{|l|}{ 2) Easy to freeze } \\
\hline Active participants / employees & $28.8 \%$ & $2.6 \%$ & $17.1 \%$ & $47.8 \%$ & $16.3 \%$ & $0.3 \%$ & $4.6 \%$ & $25.1 \%$ & $* * *$ \\
\hline Plan is collectively bargained & $40.9 \%$ & $0.0 \%$ & $0.0 \%$ & $100.0 \%$ & $30.9 \%$ & $0.0 \%$ & $0.0 \%$ & $100.0 \%$ & $* * *$ \\
\hline Hybrid plan & $16.3 \%$ & $0.0 \%$ & $0.0 \%$ & $0.0 \%$ & $10.1 \%$ & $0.0 \%$ & $0.0 \%$ & $0.0 \%$ & $* * *$ \\
\hline \multicolumn{10}{|l|}{ 3) Competitive pressures } \\
\hline Retired participants / total participants & $50.7 \%$ & $35.6 \%$ & $50.4 \%$ & $66.2 \%$ & $62.8 \%$ & $43.0 \%$ & $64.3 \%$ & $88.4 \%$ & $* * *$ \\
\hline Market capitalization & 13.6 & 0.9 & 3.0 & 10.4 & 14.9 & 0.7 & 1.7 & 13.0 & \\
\hline Percent in industry with DC plans only & $57.6 \%$ & $44.3 \%$ & $53.9 \%$ & $73.3 \%$ & $55.3 \%$ & $44.3 \%$ & $53.3 \%$ & $72.5 \%$ & $* *$ \\
\hline R\&D Expenses to sales & $2.6 \%$ & $0.4 \%$ & $1.9 \%$ & $4.7 \%$ & $2.7 \%$ & $0.2 \%$ & $1.9 \%$ & $4.7 \%$ & \\
\hline
\end{tabular}

Significance: *** 99 percent, ** 95 percent, * 90 percent, + 85 percent.

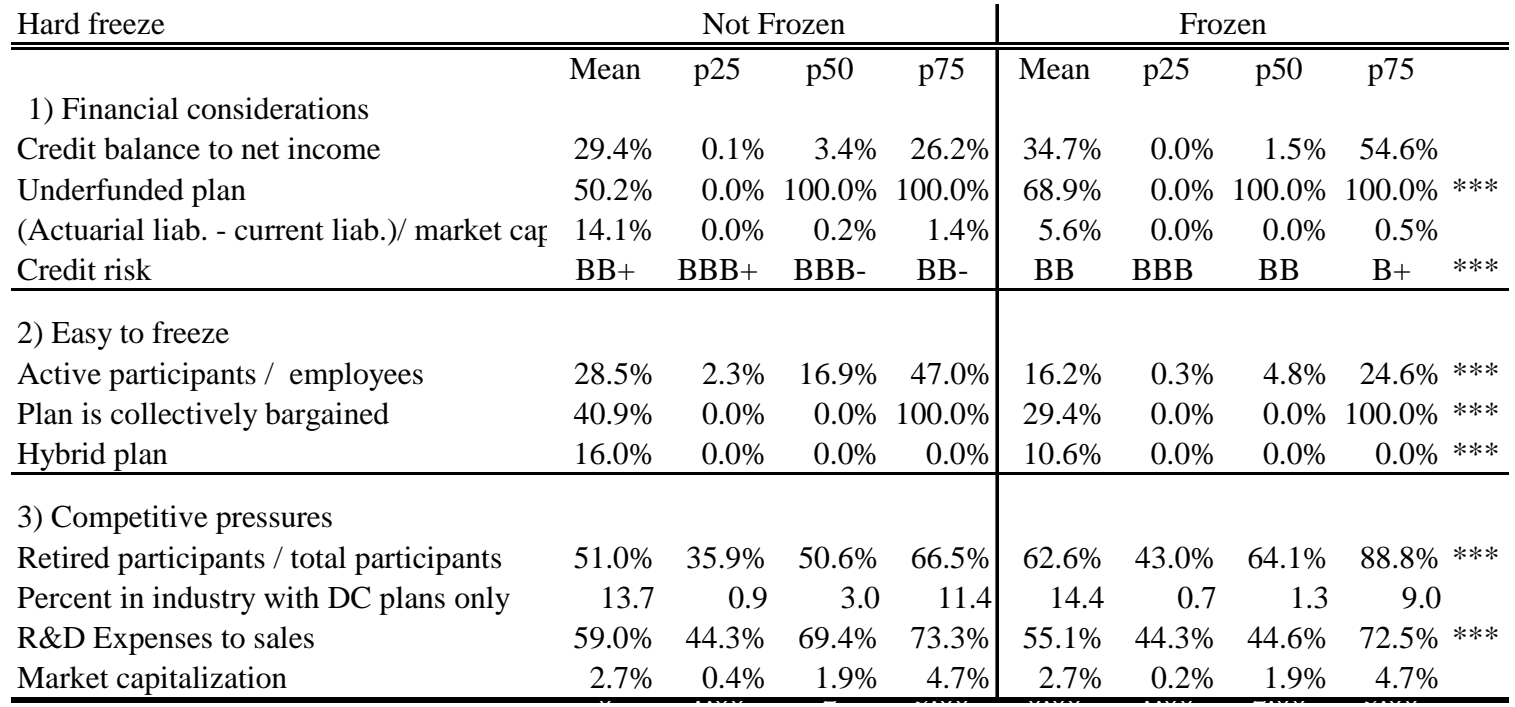

Significance: *** 99 percent, ** 95 percent, * 90 percent, + 85 percent.

Source: Authors' calculations. 
Table 7. Probability of Plan Being Frozen

\begin{tabular}{|c|c|c|c|c|}
\hline \multirow[t]{2}{*}{ Explanatory variables } & \multicolumn{4}{|c|}{ Dependent variable } \\
\hline & \multicolumn{2}{|c|}{ Any freeze } & \multicolumn{2}{|c|}{ Hard freeze } \\
\hline \multicolumn{5}{|l|}{ Potential damage to financial results } \\
\hline Credit Balance to Net Income & $\begin{array}{l}0.0093 \\
(0.007)\end{array}$ & $\begin{array}{l}0.0095+ \\
(0.007)\end{array}$ & $\begin{array}{l}0.0077 \\
(0.006)\end{array}$ & $\begin{array}{l}0.0085+ \\
(0.006)\end{array}$ \\
\hline Plan is underfunded & $\begin{array}{l}0.0365 * \\
(0.018)\end{array}$ & $\begin{array}{l}0.0337 \text { * } \\
(0.018)\end{array}$ & $\begin{array}{l}0.0584 \text { *** } \\
(0.016)\end{array}$ & $\begin{array}{l}0.0557^{\star \star \star} \\
(0.016)\end{array}$ \\
\hline $\begin{array}{l}\text { (Actuarial liab.- current liab.)/ } \\
\text { market cap }\end{array}$ & $\begin{array}{l}-0.0008 \\
(0.001)\end{array}$ & $\begin{array}{l}-0.0010 \\
(0.001)\end{array}$ & $\begin{array}{l}-0.0005 \\
(0.001)\end{array}$ & $\begin{array}{l}-0.0008 \\
(0.001)\end{array}$ \\
\hline Credit risk & $\begin{array}{l}0.0135 * * \\
(0.007)\end{array}$ & $\begin{array}{l}0.0115 \text { ** } \\
(0.005)\end{array}$ & $\begin{array}{l}0.0129 * \star \\
(0.007)\end{array}$ & $\begin{array}{l}0.0118 * * * \\
(0.004)\end{array}$ \\
\hline \multicolumn{5}{|l|}{ Cost of closing plan } \\
\hline Active participants/ employees & $\begin{array}{l}-0.2120 * * \star \\
(0.056)\end{array}$ & $\begin{array}{l}-0.2153^{\star \star \star} \\
(0.054)\end{array}$ & $\begin{array}{l}-0.1762 * \star \star \\
(0.052)\end{array}$ & $\begin{array}{l}-0.1796 * \star \star \\
(0.046)\end{array}$ \\
\hline Plan is collectively bargained & $\begin{array}{l}-0.0776 \text { *** } \\
(0.023)\end{array}$ & $\begin{array}{l}-0.0819 * \star \star \\
(0.022)\end{array}$ & $\begin{array}{l}-0.0684^{* * *} \\
(0.020)\end{array}$ & $\begin{array}{l}-0.0718 * \star \star \\
(0.019)\end{array}$ \\
\hline Hybrid plan & $\begin{array}{l}-0.0343 \\
(0.022)\end{array}$ & $\begin{array}{l}-0.0340+ \\
(0.021)\end{array}$ & $\begin{array}{l}-0.0184 \\
(0.020)\end{array}$ & $\begin{array}{l}-0.0219 \\
(0.019)\end{array}$ \\
\hline \multicolumn{5}{|l|}{ Competitive position of firm } \\
\hline $\begin{array}{l}\text { Retired participants / total } \\
\text { participants }\end{array}$ & $\begin{array}{l}0.1817 \text { *** } \\
(0.042)\end{array}$ & $\begin{array}{l}0.1817^{\star * \star} \\
(0.042)\end{array}$ & $\begin{array}{l}0.1375^{\star \star \star} \\
(0.033)\end{array}$ & $\begin{array}{l}0.1357 * \star \star \\
(0.031)\end{array}$ \\
\hline Market capitalization of firm & $\begin{array}{l}0.0009 * * * \\
(0.0003)\end{array}$ & $\begin{array}{l}0.0007^{\star \star \star} \\
(0.000)\end{array}$ & $\begin{array}{l}0.0008 * * \star \\
(0.000)\end{array}$ & $\begin{array}{l}0.0008 * * * \\
(0.000)\end{array}$ \\
\hline Percent in industry with DC plans & $\begin{array}{l}0.1753^{* *} \\
(0.070)\end{array}$ & & $\begin{array}{l}0.1923 \text { ** } \\
(0.068)\end{array}$ & \\
\hline Industry R\&D intensity & $\begin{array}{l}-0.8938 * * \\
(0.400)\end{array}$ & & $\begin{array}{l}-0.6403 * \\
(0.356)\end{array}$ & \\
\hline Industry: Ag., mining, construction & & $\begin{array}{l}-0.0158 \\
(0.051)\end{array}$ & & $\begin{array}{l}-0.0077 \\
(0.044) \\
\end{array}$ \\
\hline Industry: Mfg. Durable & & $\begin{array}{l}0.0194 \\
(0.054)\end{array}$ & & $\begin{array}{l}0.0044 \\
(0.044)\end{array}$ \\
\hline Industry: Mfg. Nondurable & & $\begin{array}{l}-0.0458 \\
(0.043)\end{array}$ & & $\begin{array}{l}-0.0789 * * \\
(0.030)\end{array}$ \\
\hline Industry: Transportation & & $\begin{array}{l}-0.0009 \\
(0.084)\end{array}$ & & $\begin{array}{l}-0.0601 \\
(0.031)\end{array}$ \\
\hline Industry: Utilities & & $\begin{array}{l}-0.0602 \\
(0.042) \\
\end{array}$ & & $\begin{array}{l}-0.0455 \\
(0.035)\end{array}$ \\
\hline Industry: FIRE & & $\begin{array}{l}0.1229 * * \\
(0.075)\end{array}$ & & $\begin{array}{l}0.1025 * \\
(0.067)\end{array}$ \\
\hline Industry: Services & & $\begin{array}{l}0.0237 \\
(0.049)\end{array}$ & & $\begin{array}{l}0.0151 \\
(0.041)\end{array}$ \\
\hline Industry: Missing & & $\begin{array}{l}0.1065 \\
(0.253) \\
\end{array}$ & & $\begin{array}{l}0.1038 \\
(0.239) \\
\end{array}$ \\
\hline Pseudo $\mathrm{R}^{2}$ & 0.1008 & 0.1134 & 0.1131 & 0.1421 \\
\hline Observations & 1,784 & 1,802 & 1,784 & 1,802 \\
\hline
\end{tabular}

Note: Significance: *** 99 percent, ** 95 percent, * 90 percent, + 85 percent. Figures in parentheses are robust standard errors. 
Figure 1. Private Sector Workers with Pension Coverage, by Pension Type, 1980-2004

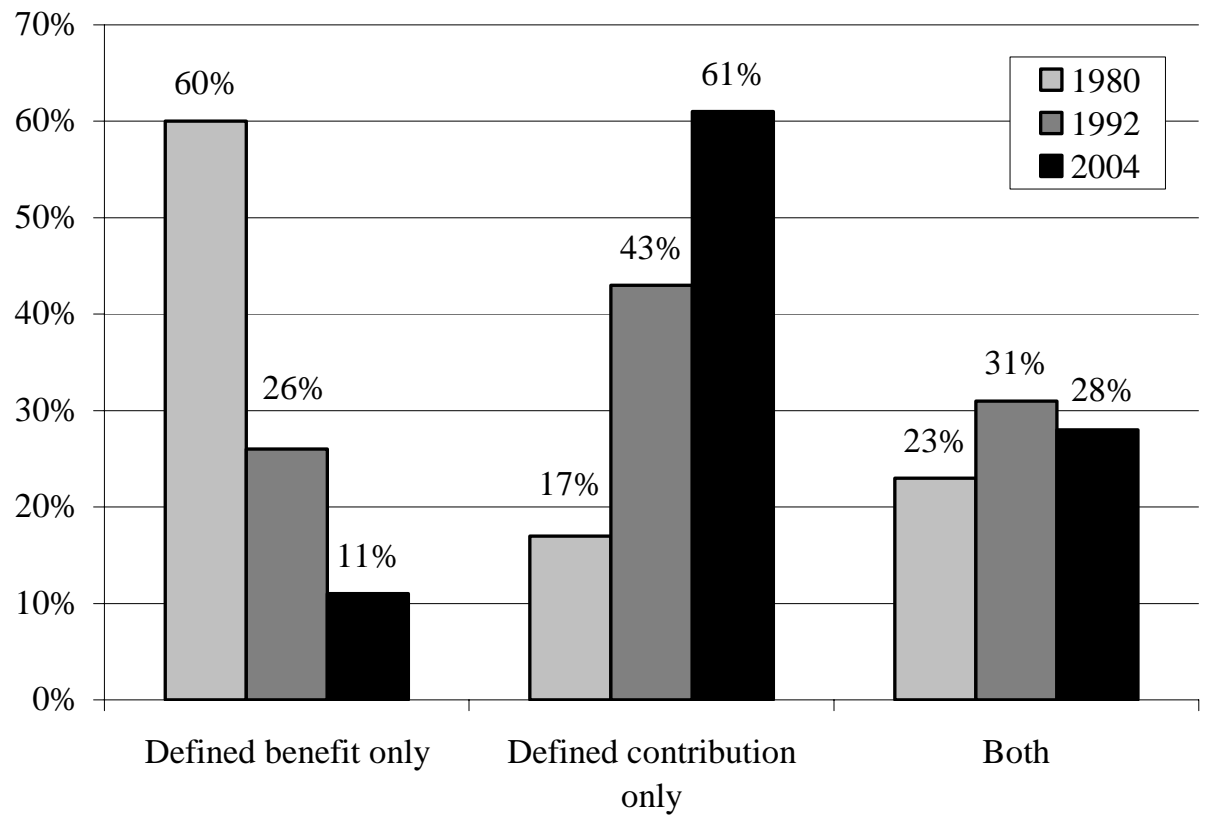

Note: Although these calculations adjust for double-counting, some overestimation of coverage may still remain.

Sources: U.S. Department of Labor (2004); and authors' calculations from U.S. Department of Labor (2006). 
Figure 2. Net Growth of Pension Plans, thousands, 1960-2006

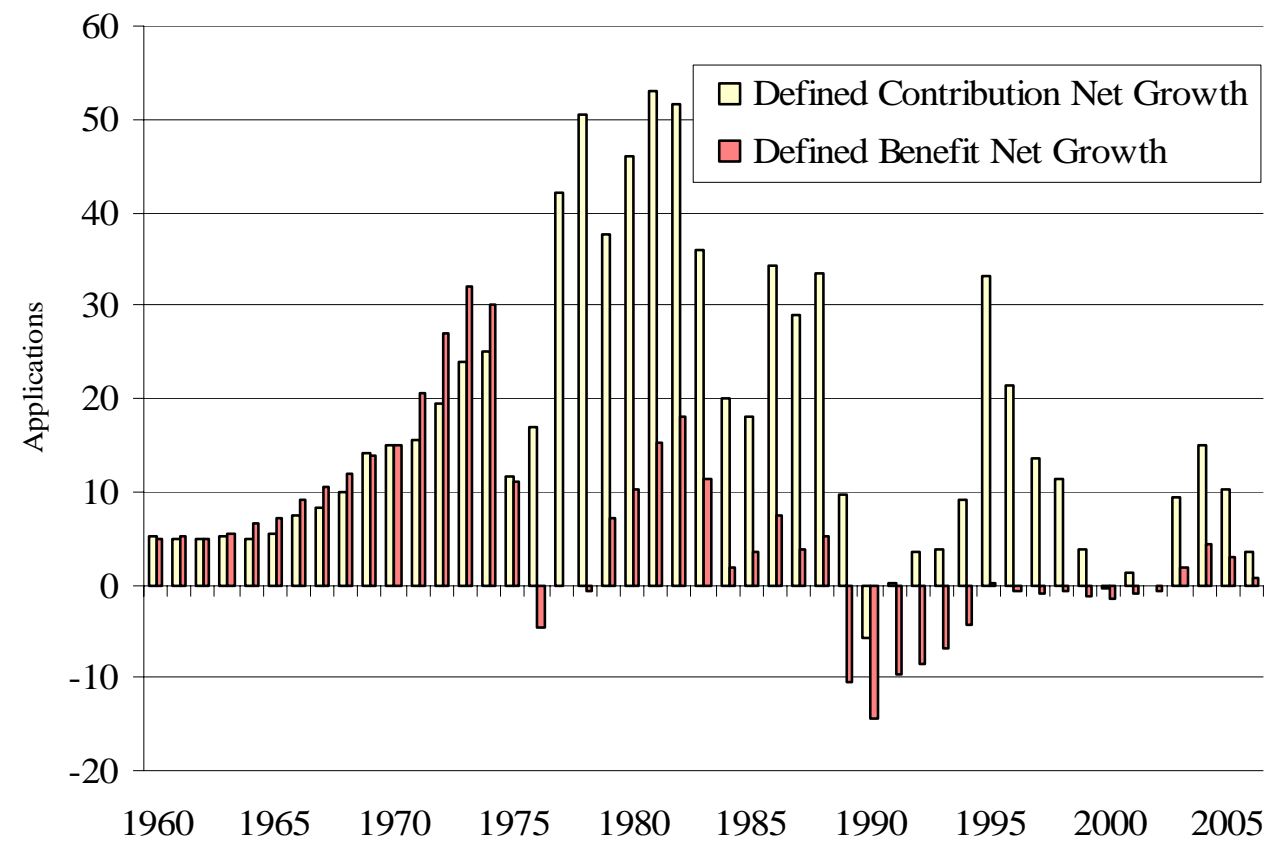

Sources: Data for 1960-1976 are estimated using Figure 1 from Warshawsky (1995); Data for 1977-1987 were estimated using data from McGill et. al. (1996); Data for 1988-2006 are from IRS Data Books (19882006). 
Figure 3. Defined Benefit Plans, Contributions and Benefits, billions, 1955-2004

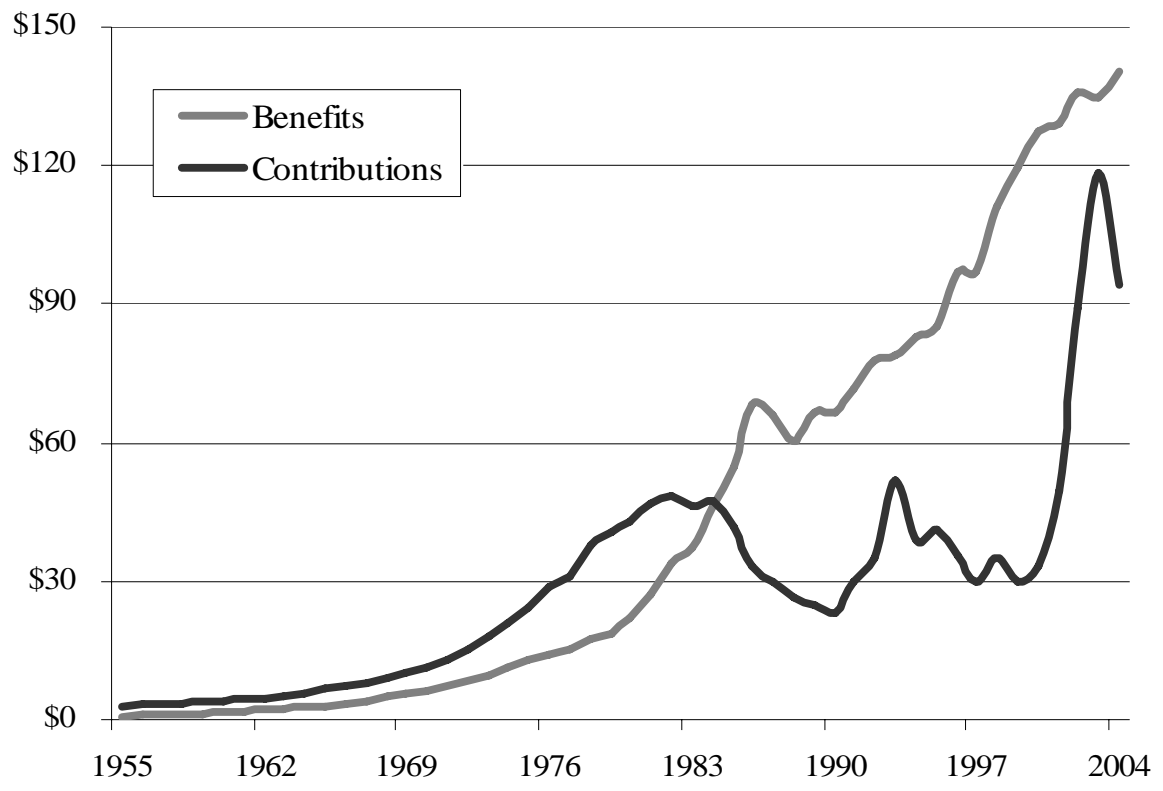

Sources: DOL Private Pension Plan Bulletin (1975-2004); U.S. Department of Commerce National Income and Product Accounts (1955-1975). 
Figure 4. Percent of Large Plans with Assets Greater than Current Liability for Accrued Benefits, 1979-2006

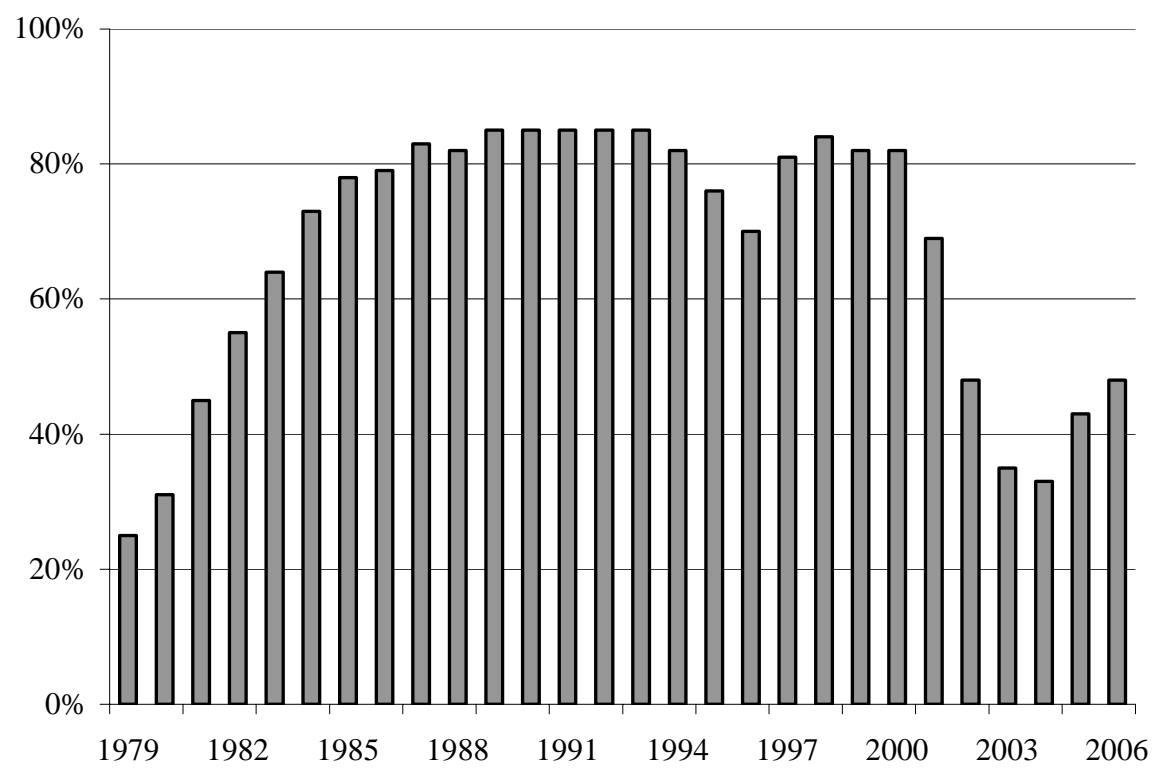

Note: Current liability is the actuarial present value of accrued benefits using assumptions specified by the internal revenue service. The value is disclosed in the plan's Form 5500 Schedule B. The interest rate used in this calculation was between 90 percent and 105 percent of the 30-year Treasury over the past 4 years. The Job Creation and Worker Assistance Act of 2002 increased the limit to 120 percent for 2002 and 2003. The Pension Equity Funding Act of 2004 raised the rate to the long-term average of the corporate bond rate for 2004 and 2005. The Pension Protection Act of 2006 extended the use of the corporate bond rate for 2006.

Source: Watson Wyatt Worldwide (1986, 1992, 1998, 2001, 2003, 2006). 
Figure 5. Pension Freezes, Type of Freeze and Percent.

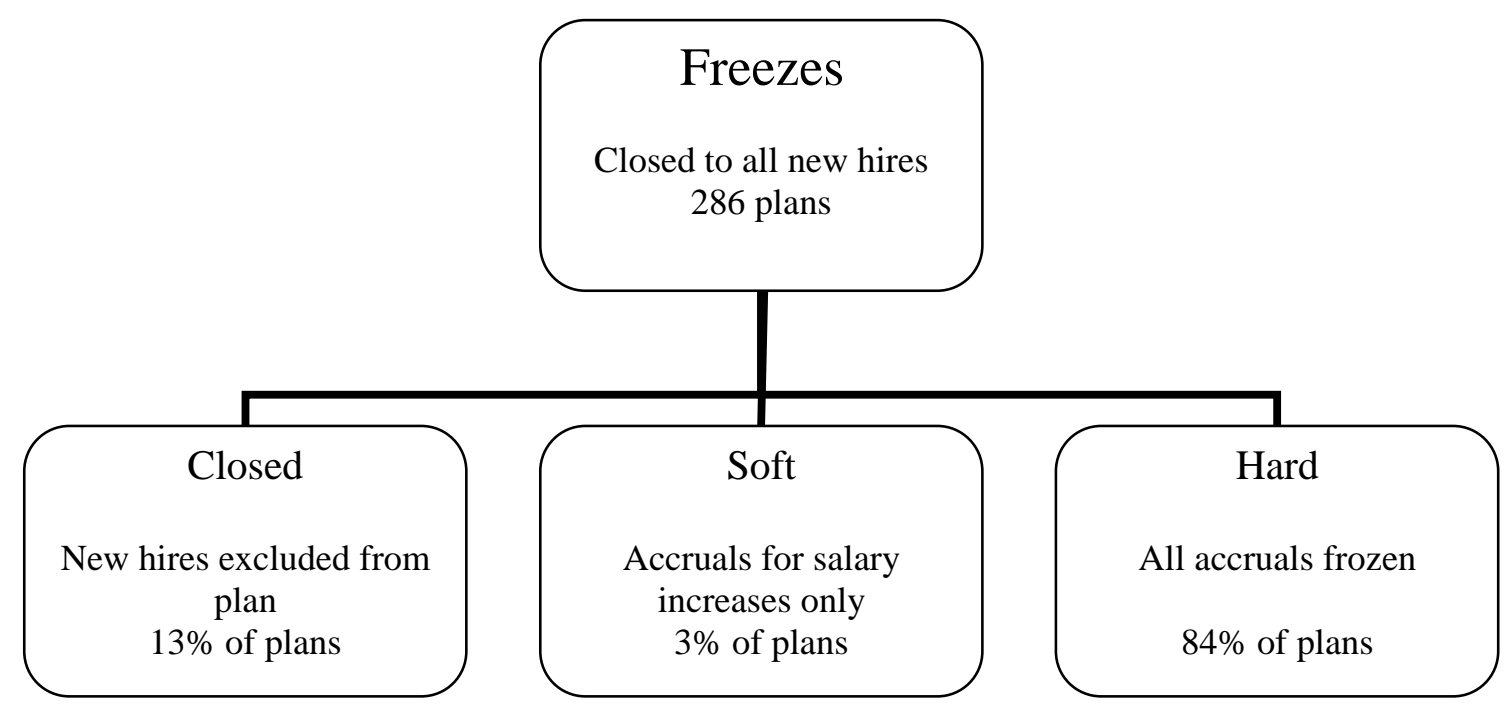

Source: Authors’ calculations. 
Appendix Table 1. Plan Freezes: Companies That Froze Their Plans (with \$100 million or more in assets), 2002-2006

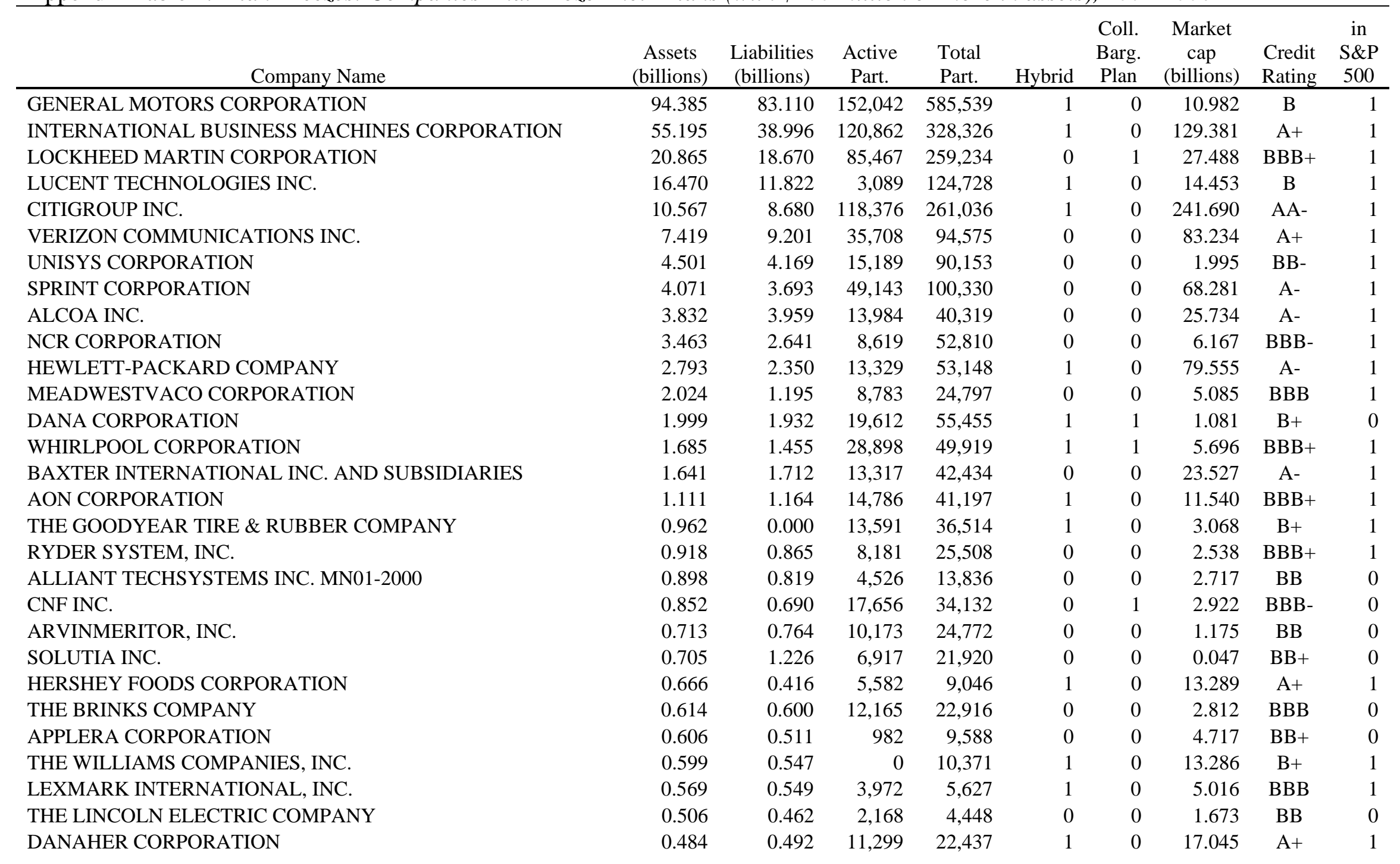


Company Name

PNM RESOURCES, INC.

LINCOLN NATIONAL CORPORATION

IKON OFFICE SOLUTIONS, INC.

BELO CORP.

EMC CORPORATION

MCKESSON CORPORATION

HOSPIRA, INC.

NORTHWEST AIRLINES, INC

BAKER HUGHES INCORPORATED

MEDIA GENERAL, INC.

LANDAMERICA FINANCIAL GROUP, INC

FOSTER WHEELER INC

TREDEGAR CORPORATION

CIRCUIT CITY STORES, INC.

THE REYNOLDS AND REYNOLDS COMPANY

DUPONT PERFORMANCE ELASTOMERS, LLC

FERRO CORPORATION

HARLEYSVILLE GROUP INC

IMPERIAL SUGAR CORPORATION

COCA-COLA BOTTLING CO. CONSOLIDATED

LOCKHEED MARTIN SPECIALTY COMPONENTS, INC.

TYCO INTERNATIONAL US INC.

MAGNETEK, INC.

FIRST DATA CORPORATION

RUSSELL CORP

WARNACO INC.

BANDAG, INCORPORATED

THE INTERPUBLIC GROUP OF COMPANIES, INC.

SUREWEST COMMUNICATIONS

JOURNAL REGISTER EAST, INC.

Source: Authors' calculations.

\begin{tabular}{|c|c|c|c|c|c|c|c|c|}
\hline $\begin{array}{r}\text { Assets } \\
\text { billions) }\end{array}$ & $\begin{array}{r}\text { Liabilities } \\
\text { (billions) }\end{array}$ & $\begin{array}{r}\text { Active } \\
\text { Part. }\end{array}$ & $\begin{array}{l}\text { Total } \\
\text { Part. }\end{array}$ & Hybrid & $\begin{array}{c}\text { Coll. } \\
\text { Barg. } \\
\text { Plan }\end{array}$ & $\begin{array}{r}\text { Market } \\
\text { cap } \\
\text { (billions) }\end{array}$ & $\begin{array}{l}\text { Credit } \\
\text { Rating }\end{array}$ & $\begin{array}{r}\text { S\&P } \\
500\end{array}$ \\
\hline 0.481 & 0.476 & 1,611 & 3,875 & 0 & 0 & 1.685 & BBB & \\
\hline 0.474 & 0.379 & 4,534 & 11,197 & 1 & 0 & 9.215 & A- & \\
\hline 0.472 & 0.453 & 15,905 & 34,365 & 0 & 0 & 1.355 & BB & \\
\hline 0.389 & 0.354 & 2,547 & 9,489 & 0 & 0 & 2.307 & BBB & \\
\hline 0.365 & 0.308 & 1,222 & 5,757 & 0 & 0 & 32.472 & BBB & \\
\hline 0.355 & 0.286 & 1,553 & 9,790 & 0 & 0 & 15.848 & BBB & \\
\hline 0.284 & 0.297 & 8,452 & 8,624 & 0 & 0 & 6.916 & BBB & \\
\hline 0.284 & 0.431 & 4,734 & 9,147 & 0 & 0 & 0.047 & $\mathrm{D}$ & \\
\hline 0.269 & 0.114 & 1,426 & 4,066 & 0 & 0 & 20.756 & A- & \\
\hline 0.265 & 0.241 & 5,699 & 9,359 & 0 & 0 & 1.219 & BBB- & \\
\hline 0.250 & 0.232 & 8,602 & 13,322 & 1 & 0 & 1.079 & BBB- & \\
\hline 0.235 & 0.303 & 688 & 6,914 & 1 & 0 & 2.113 & B- & \\
\hline 0.228 & 0.157 & 1,903 & 5,192 & 0 & 0 & 0.499 & B & \\
\hline 0.227 & 0.180 & 18,959 & 28,568 & 0 & 0 & 4.200 & $\mathrm{BB}+$ & \\
\hline 0.221 & 0.191 & 3,601 & 6,021 & 0 & 0 & 1.718 & BBB & \\
\hline 0.198 & 0.187 & 1,115 & 1,738 & 0 & 0 & 39.083 & A & \\
\hline 0.183 & 0.232 & 1,160 & 3,492 & 0 & 0 & 2.981 & $\mathrm{BB}$ & \\
\hline 0.146 & 0.138 & 1,960 & 4,167 & 0 & 0 & 0.811 & BBB- & \\
\hline 0.146 & 0.171 & 569 & 2,832 & 0 & 0 & 0.143 & BBB- & \\
\hline 0.144 & 0.135 & 4,275 & 8,173 & 0 & 0 & 0.391 & BBB & \\
\hline 0.140 & 0.105 & 0 & 1,446 & 0 & 0 & 27.488 & $\mathrm{BBB}+$ & \\
\hline 0.139 & 0.128 & 1,269 & 6,152 & 0 & 1 & 56.114 & BBB+ & \\
\hline 0.135 & 0.179 & 322 & 8,768 & 1 & 0 & 0.074 & $\mathrm{BB}+$ & \\
\hline 0.131 & 0.145 & 1,901 & 6,339 & 0 & 0 & 32.808 & $\mathrm{~A}^{+}$ & \\
\hline 0.126 & 0.149 & 4,719 & 10,251 & 0 & 0 & 0.446 & $\mathrm{~B}^{+}$ & \\
\hline 0.114 & 0.142 & 1,078 & 5,844 & 0 & 0 & 1.232 & BB- & \\
\hline 0.113 & 0.076 & 1,106 & 1,661 & 0 & 0 & 0.829 & $\mathrm{~B}$ & \\
\hline 0.109 & 0.138 & 1,309 & 4,916 & 1 & 0 & 4.149 & $\mathrm{~B}^{+}$ & \\
\hline 0.107 & 0.094 & 963 & 1,241 & 0 & 0 & 0.386 & BB- & \\
\hline 0.106 & 0.099 & 1,903 & 4,603 & 0 & 0 & 0.604 & BB & \\
\hline
\end{tabular}


Appendix Table 2. Prediction: Companies Likely to Freeze Their Plans Next (with $\$ 100$ million or more in assets)

\begin{tabular}{|c|c|c|c|c|c|c|c|c|c|c|c|}
\hline & & & & & sion & & & & & Firm & \\
\hline Company Name & Prob & $\begin{array}{c}\text { Assets } \\
\text { (billions) }\end{array}$ & $\begin{array}{c}\text { Liabilities } \\
\text { (billions) }\end{array}$ & $\begin{array}{c}\text { Credit } \\
\text { balance }\end{array}$ & $\begin{array}{c}\text { Active } \\
\text { Part. }\end{array}$ & $\begin{array}{l}\text { Total } \\
\text { Part. }\end{array}$ & Hybrid & $\begin{array}{l}\text { Coll. } \\
\text { Barg. } \\
\text { Plan }\end{array}$ & $\begin{array}{c}\text { Market } \\
\text { cap } \\
\text { (billions) }\end{array}$ & $\begin{array}{l}\text { Credit } \\
\text { Rating }\end{array}$ & $\begin{array}{c}\text { in } \\
\text { S\&P } \\
500 \\
\end{array}$ \\
\hline DAIMLERCHRYSLER CORPORATION & 0.3489 & 2.837 & 2.911 & 1.566 & 18,266 & 42,946 & 0 & 0 & 51.957 & $\mathrm{BBB}$ & 0 \\
\hline BANK OF AMERICA CORPORATION & 0.3758 & 2.425 & 1.931 & 0.281 & 33,564 & 83,600 & 1 & 0 & 184.586 & AA- & 1 \\
\hline UNITED AIR LINES, INC. & 0.3748 & 1.544 & 2.326 & 0.000 & 18,813 & 42,318 & 0 & 0 & 8.447 & $\mathrm{D}$ & 0 \\
\hline ALLSTATE INSURANCE COMPANY & 0.3987 & 0.983 & 0.849 & 0.252 & 120 & 9,582 & 0 & 0 & 34.929 & $\mathrm{~A}+$ & 1 \\
\hline CREDIT SUISSE FIRST BOSTON, LLC & 0.4129 & 0.693 & 0.484 & 0.244 & 2,313 & 6,523 & 0 & 0 & 72.223 & $\mathrm{BBB}$ & 0 \\
\hline CAR-RT-SORT CR05 & 0.4284 & 0.542 & 0.591 & 0.120 & 680 & 11,597 & 0 & 0 & 3.596 & BBB- & 0 \\
\hline EQUIFAX INC. & 0.3487 & 0.514 & 0.427 & 0.092 & 1,633 & 11,070 & 0 & 0 & 4.912 & A- & 1 \\
\hline THE STANDARD REGISTER COMPANY & 0.4076 & 0.362 & 0.391 & 0.059 & 3,702 & 11,165 & 1 & 0 & 0.456 & $\mathrm{BB}+$ & 0 \\
\hline POLYONE CORPORATION & 0.4549 & 0.336 & 0.373 & 0.015 & 635 & 6,506 & 0 & 0 & 0.591 & $\mathrm{~B}+$ & 0 \\
\hline CRAWFORD \& COMPANY \& SUBSIDIARIES & 0.3901 & 0.314 & 0.339 & 0.030 & 2,393 & 7,265 & 0 & 0 & 0.282 & $\mathrm{BBB}$ & 0 \\
\hline HILTON HOTELS CORPORATION & 0.3821 & 0.278 & 0.267 & 0.000 & 2,265 & 10,071 & 0 & 0 & 9.210 & BBB- & 1 \\
\hline TENET HEALTHCARE CORPORATION & 0.4963 & 0.252 & 0.268 & 0.055 & 5,593 & 20,368 & 0 & 0 & 3.598 & B & 1 \\
\hline WALTER INDUSTRIES, INC. & 0.402 & 0.203 & 0.199 & 0.030 & 947 & 3,925 & 0 & 0 & 1.941 & $\mathrm{~B}+$ & 0 \\
\hline CENDANT CORPORATION & 0.3655 & 0.178 & 0.204 & 0.000 & 856 & 4,555 & 0 & 0 & 17.450 & $\mathrm{BBB}+$ & 1 \\
\hline VISHAY INTERTECHNOLOGY, INC. & 0.3753 & 0.131 & 0.114 & 0.028 & 1,001 & 2,981 & 0 & 0 & 2.534 & BB & 0 \\
\hline
\end{tabular}

Source: Authors’ calculations. 


\section{RECENT WORKING PAPERS FROM THE}

\section{CENTER FOR RETIREMENT RESEARCH AT BOSTON COLLEGE}

Capital Income Flows and the Relative Well-Being of America's Aged Population Barry P. Bosworth, Gary Burtless, and Sarah E. Anders, November 2007

The Role of Governance in Retirement Investments: Evidence from Variable Annuities

Richard Evans and Rudiger Fahlenbrach, October 2007

A New Approach to Raising Social Security's Earliest Eligibility Age

Kelly Haverstick, Margarita Sapozhnikov, Robert Triest, and Natalia Zhivan, October 2007

What Makes Retirees Happier: A Gradual or 'Cold Turkey' Retirement? Esteban Calvo, Kelly Haverstick, and Steven A. Sass, October 2007

Why Do Married Men Claim Social Security Benefits So Early? Ignorance, Caddishness, or Something Else?

Steven A. Sass, Wei Sun, and Anthony Webb, October 2007

Measurement Error in Earnings Data in the Health and Retirement Study

Jesse Bricker and Gary V. Engelhardt, October 2007

Evaluating the Advanced Life Deferred Annuity - An Annuity People Might Actually Buy

Guan Gong and Anthony Webb, September 2007

Population Aging, Labor Demand, and the Structure of Wages Margarita Sapozhnikov and Robert K. Triest, September 2007

Work at Older Ages: Is Raising the Early Retirement Age an Option for Social Security Reform?

John A. Turner, August 2007

The Labor Supply of Older Americans

Alicia H. Munnell and Steven A. Sass, May 2007

Why Do Japanese Workers Remain in the Labor Force So Long?

John B. Williamson and Masa Higo, May 2007 